Trakya Üniversitesi

Eğitim Fakültesi Dergisi

Cilt 8, Say1 2

Ocak 2018 214-240

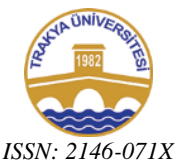

ISSN: $2146-071 X$
Trakya University

Journal of Education Faculty

Volume 8 , Issue 2

January 2018, 214-240

\title{
Spektroskopik Analiz Yöntemi Uygulamalarında Proje Tabanlı Öğrenme Yaklaşımının Kimya Öğretmen Adaylarının Akademik Başarılarına Etkisi ${ }^{1}$
}

\section{Effect of Project Based Learning on Academic Achievement of Chemistry Teacher Candidates in the Application of Spectroscopic Analysis Method}

\author{
Sibel KILINÇ ALPAT ${ }^{2}$, Özge ÖZBAYRAK AZMAN ${ }^{3}$, Şenol ALPAT ${ }^{4}$
}

Öz: Bu çalışmada, Analitik Kimya laboratuvar dersi "Işık-madde etkileşimine dayanan UV/Görünür bölge spektroskopik analiz yöntemi uygulamaları" konusunda, proje tabanlı öğrenme yaklaşımının öğrencilerin akademik başarılarına etkisi incelenmiştir. Araştırmada, ön ve son test kontrol gruplu yarı deneysel desen kullanılmıştır. Konu, deney grubunda proje tabanlı öğrenme yaklaşımı ile kontrol grubunda ise öğretim programına uygun şekilde yürütülmüştür. Son test akademik başarı puanlarının Mann-Whitney U Testi analizi sonuçlarına göre; öğrencilerin akademik başarılarında proje tabanlı öğrenme yaklaşımının kullanıldığ 1 deney grubu lehine anlamlı bir fark olduğu gözlenmiştir $(\mathrm{p}<.05)$. Wilcoxon işaretli sıralar testi sonuçları; deney ve kontrol gruplarının her ikisinde de grup içi akademik başarı puanlarında artış olduğunu göstermiştir. Cohen's d değerine göre, deney grubunda uygulanan öğrenme yaklaşımının büyük etki değerine sahip olduğu söylenebilir $(\mathrm{d}=0,88)$. Yarı yapılandırılmış görüşmelerin içerik analizinden elde edilen sonuçlar, deney grubu öğrencilerinin konunun uygulanan öğrenme yaklaşımı ile işlenmesini daha akılda kalıcı bulduklarını göstermiştir.

Anahtar Kelimeler: Analitik Kimya, Işık-madde Etkileşimi, Proje Tabanl Öğrenme Yaklaşımı, Görüşme, Mann-Whitney U testi

\begin{abstract}
In this work, the effect of project based learning approach on students' academic achievement on the topic of "Application of UV/Visible spectroscopic analysis method based on light-matter interaction" in Analytical Chemistry Laboratory lesson. Pre- and post-test quasi experimental design with control group was applied in this research. In the experimental group, the subject was carried out with the project based learning approach and in the control group in accordance with the teaching program. It was observed that there was a significant difference in the students' academic achievement in favour of the experimental group in which the project based learning approach was used according to the Mann-Whitney U test analysis results of the post-test
\end{abstract}

\footnotetext{
${ }^{1}$ Bu çalışma, IV. Ulusal Kimya Eğitimi Kongresi'nde (UKEK 2015) bildiri olarak sunulmuştur.

${ }^{2}$ Prof. Dr., Dokuz Eylül Üniversitesi, Buca Eğitim Fakültesi, Kimya Eğitimi Anabilim Dalı, e-posta: skilincalpat@gmail.com

${ }^{3}$ Dr., Dokuz Eylül Üniversitesi, Buca Eğitim Fakültesi, Kimya Eğitimi Anabilim Dalı, e-posta: ozgeozbayrak@gmail.com

${ }^{4}$ Doç. Dr., Dokuz Eylül Üniversitesi, Buca Eğitim Fakültesi, Kimya Eğitimi Anabilim Dalı, e-posta: senolalpat01@gmail.com
} 
academic achievement scores $(\mathrm{p}<.05)$. Wilcoxon signed rank test results showed that the increase of students' academic achievement of within both groups. It can be also stated that project based learning approach has a great effect size considering to Cohen's d value $(\mathrm{d}=0.88)$. Content analysis of semistructured interview results demonstrated that the experimental group students find it more memorable to process the subject with an applied approach.

Keywords: Analytical Chemistry Laboratory, light-matter interaction, project based learning approach, interview, Mann-Whitney U test

\section{GİRIŞ̧}

Eğitim, bireyleri yaşama hazırlamayı ve günlük yaşamda gerçekleşen olayları anlamalarını sağlamayı amaçlar. Bu amacın gerçekleştirilmesinde; öğrencilerin doğa ile doğada meydana gelen olaylar arasındaki ilişkileri anlamalarını ve günlük hayatta karşılaşabilecekleri problemlere mantıklı çözümler üretebilmelerini sağlayan fen bilimleri önemli bir role sahiptir (Coştu, Ayas, \& Ünal, 2007). Öğrencilerin fizik, kimya ve biyoloji gibi fen bilimleri derslerinde başarılı olabilmeleri, bilimin ne olduğunu ve doğasını doğru kavrayabilmeleri ile orantılıdır. Bilimin doğasında; doğadaki olayların gözlemlenmesi sonucu bilimsel bilgilerin açığa çıkması, bilimsel bilginin yaratıcılık ve hayal gücü ürünü olduğu fikri yatmaktadır. Bilim; deneysel gözlemler sayesinde olayları birbirine bağlayan yasaları bulmaya çalışır. Bilimde mevcut bilgilerin üzerine yeni bilgilerin eklendiği sürekli bir değişim vardır (Türkmen \& Yalçın, 2001). Fen bilimleri alanında verilen iyi bir eğitim ile bilimin doğasını anlayan, bilim ve teknoloji konusunda farkındalığa sahip bireylerin yetiştirilmesi mümkün olacaktır (Doğanay, Demircioğlu, \& Yeşilpınar, 2014).

Fen bilimleri alanında yer alan kimya dalı soyut ve karmaşık konular içermektedir. Öğrenciler karmaşık ve soyut kavramlar içeren kimya konularını öğrenmekte zorluklar yaşamaktadır. Kimya konularının anlaşılma zorluklarının önüne geçebilmek için kavramların somutlaştırılarak anlatılması önemlidir. Bu durum uygun öğretim yöntemlerinin derslerde kullanılması ile mümkün olmaktadır (Apedoe, Ellefson, \& Schunn, 2012; Díaz-Vázquez et al., 2012; Sert Çıbık \& Yalçın, 2012). Öğrenci başarısının artması için öğrencilerin problem çözme becerilerini geliştiren, ezberden uzaklaştıran uygun aktif öğrenme yaklaşımları kullanılmalıdır. Bu yaklaşımlar arasında yer alan proje tabanlı öğrenme yaklaşımı; sadece sınıf ortamı yerine, öğrencilerin laboratuvar ortamını da etkin olarak kullanmasına olanak sağlayan bir yaklaşımdır. Kimya ile ilgili soyut bilgilerin somutlaştırılması, günlük hayatla bağlantı kurulması ve öğrenciler tarafından daha kolay anlaşılır hale gelmesi amacıyla kimya eğitiminde laboratuvar ortamları yaygın olarak kullanılmaktadır (Díaz-Vázquez et al., 2012; Morgil, Seyhan, \& Seçken, 2009). Laboratuvar ortamları öğrencilerin bilimsel yöntem sürecine etkin olarak katıldıkları ortamlardır. Bilimsel yöntem sürecinde; problem belirlendikten sonra, probleme yönelik gözlemler ile veriler toplanır, hipotezler kurulur, hipoteze yönelik tahminler yapılarak bu tahminler yapılan deneyler ile sınanır. Laboratuvarların etkin bir öğrenme ortamına dönüştürülmesi, öğrenme sürecinin etkili olabilmesi açısından son derece önemlidir (Feyzioğlu ve diğerleri, 2011) Kavramları somut bir şekilde anlatabilmek ve laboratuvarları amacına uygun bir şekilde kullanabilmek projeler ile mümkün olabilmektedir (Sert Çıbık \& Yalçın, 2012).

Son yıllarda Fen eğitimcileri öğrencilerin öğrenmesini kolaylaştırmak ve etkili bir şekilde öğrenmelerine olanak sağlamak için laboratuvarda bilimsel sürece uygun 
uygulamalar yapmaya çalışmaktadırlar. (Díaz-Vázquez et al., 2012; Feyzioğlu vd., 2011). O'Hara ve Sanborn (1999), Exstrom ve Mosher (2000), Juhl ve diğerleri (1997), Harle ve diğerleri (2003), Selco ve diğerleri (2003) ve Arnold (2003) gibi araştırmacılar; proje tabanlı öğrenme yaklaşımını laboratuvarda yapılan deneylerle birleştirmişlerdir. Bu sayede öğrencilerin araştırma yaparak bulguları inceleyip bir ürün oluşturma yetenekleri geliştirilmiştir (Morgil, Seyhan, \& Seçken, 2009).

Proje tabanlı öğrenme yaklaşımı öğrenci merkezli bir yaklaşım olup, bu yaklaşımda öğrenciler tek başlarına ya da küçük gruplar halinde çalışarak somut ürünler ortaya koymaya çalışırlar. Uygulama sürecinde öğrenciler araştırmalarını eğitim yönlendiricisi danışmanlığında yürütürler. Öğrenciler uygulama süreci sonunda genellikle bir sonuca ulaşır ve sonuçlarını rapor haline getirirler (Bell, 2010). Proje tabanlı öğrenme yaklaşımı ile; öğrencilerin daha iyi araştırma yapabilmeleri, sunum yapabilmeleri, problem çözme ve düşünme becerisi gibi özellikleri kazanmaları mümkün olmaktadır (Bell, 2010; Gültekin, 2005).

Kimya eğitiminde öğrencilerin lisans öğrenimleri süresince almış oldukları laboratuvar dersleri öğrencilerin temel laboratuvar becerisi kazanmalarına olanak sağlar. Temel laboratuvar becerilerinin yansıra öğrencilerin bağımsız seçimler yaparak problemlere çözüm önerisi getirebilmesi etkili bir öğretim ortamının sağlanması açısından oldukça önemlidir (Adami, 2006). Proje tabanlı öğrenme yaklaşımının üniversite lisans düzeyi laboratuvar derslerinde uygulanması ile; öğrencilerin bilimsel yönteme aşina olmaları ve problemlere çözüm önerisi getirebilmeleri sağlanabilir.

Analitik Kimya laboratuvarında nitel ve nicel analiz metotları ile maddenin yapısını aydınlatmayı amaçlayan deneyler yer almaktadır. Klasik ya da enstrümental analiz yöntemleri ile gerçekleştirilen analizler öğrencilere analiz yeteneğinin yanı sıra problemlere çözüm üretme firsatı vermektedir. Analitik kimya laboratuvarlarında öğrencilerin özellikle enstrümental analiz yöntemlerinin kullanıldığı deneyler ile aşina olmaları, hem cihaz kullanma becerilerinin hem de problem çözme becerilerinin gelişmesine olanak sağlamaktadır. Spektroskopik yöntemler, elektroanalitik yöntemler, kromatografik yöntemler ve diğer bazı yöntemleri temel alan enstrümental analiz yöntemleri bilimsel çalışmaların yanı sıra, çevre atık su ya da klinik analizler olmak üzere değişik sektörlerde yaygın olarak kullanılmaktadır. Enstrümental analiz yöntemleri içerisinde yer alan spektroskopik yöntemler ile maddenin bileşiminin aydınlatılması, 1şık-madde etkileşimini esas alan analizler ile gerçekleştirilebilmektedir. Işığın dalga mekaniği ve tanecik özelliğinin aydınlatılması ile spektroskopik analiz yöntemleri kullanılır hale gelmiştir. Işı̆̆ın dalga ve tanecik özelliği sayesinde bir örnekte bulunan bir atom, molekül veya iyonun bir enerji düzeyinden diğerine geçişleri sırasında yayılan veya absorplanan 1şımanın ölçülmesi sağlanır. Spektroskopik yöntemler ile yüklü ya da yüksüz taneciklerle maddenin etkileşmesi sonucunda oluşan olaylar incelenir. Işık-madde etkileşimi 1 şının elektriksel alanı ve maddenin bağ elektronları arasında gerçekleşir. Madde ile $1 s ̧ 1 k$ etkileşmesi sonucunda ışının kırılması, yansıması, dağılması, Raman saçılması ve absorplanması gibi olaylar söz konusudur (Gündüz, 2007; Yıldız, Genç, \& Bektaş, 1997)

Iş̧k-madde etkileşiminin kimya laboratuvar uygulamalarında yer alması öğrencilerin günlük hayatta olan doğal olayların ışık-madde etkileşimi ile bağlantısını irdelemelerine de katkı sağlayabilir. Yansıma, kırılma, soğurma gibi 1şık-madde etkileşimi sonucu oluşan olayların doğadaki pek çok olayın temelini oluşturduğu 
bilinmektedir. Maddelerin neden renkli olduğu, gökkuşağının nasıl oluştuğu ve gökyüzünün neden mavi göründügü gibi soruların cevabı bu tür 1ş1k-madde etkileşimi sonucu oluşan olaylar ile ilişkilidir (URL 1, URL 2).

\subsection{Literatür Taraması}

Işık ve madde etkileşimiyle ile ilgili yapılan çalışmalar incelendiğinde; lisans düzeyinde kimya eğitimi alanında yapılan herhangi bir çalışma olmadığı, daha çok ilköğretim düzeyinde fizik eğitimi alanında ya da fen eğitimi alanında yapılan çalışmalar olduğu görülmüştür.

Şaşmaz Ören ve Erdem (2014) yılında yaptıkları çalışmalarında; 1şığın kırılması, 1şı̆̆ın soğurulması, maddeler neden renkli görünür, mercekler ve kullanım alanlarını içeren kavram karikatürleriyle zenginleştirilmiş bir materyal geliştirmişler ve bu materyali ilköğretim düzeyinde uygulamışlardır.

Ünal Çoban ve Ergin (2013) çalışmalarında ilköğretim 1şık konusunda deney grubu öğrencilerine modellemeye dayalı öğretim uygulamışlardır. Çalışmanın sonucu; modellemeye dayalı öğretim uygulanan öğrencilerde nitel olarak bilimsel bilgiye yönelik gelişmenin kontrol grubu öğrencilerine göre daha fazla olduğunu, nicel olarak ise iki grup arasında anlamlı bir fark olmadığını göstermiştir.

Uzoğlu ve diğerleri (2013) çalışmalarında; 1şık konusundaki kavram yanılgılarını açığa çıkarmışlardır. Bunun için açık uçlu sorular ve kavram karikatürlerinden yararlanmışlardır. Kavram yanılgılarının belirlenmesinde, kavram karikatürleri ve açık uçlu soruların her ikisinin de etkin olduğu sonucuna ulaşmışlardır.

Şen (2003) çalışmasında; optiğin temel konularından aynalar, görme olayı ve 1şık konularında kavram yanılgılarını ve öğrenmedeki zorlukları tespit etmişlerdir, sonuçların uluslararası düzeyde yapılan diğer çalışmalarla da uyumlu olduğunu bulmuşlardır.

Taşlıdere ve Bedur (2015) çalışmalarında; ışığın mercek ile etkileşimi konusunun anlaşılmasında düz anlatımın etkisini incelemişlerdir. Çalışma Fen bilgisi öğrencileri ile yürütülen ve sunuş stratejisi kullanılarak gerçekleştirilen öğretim sonucunda yapılan istatistiki analizler, öğrencilerin ön ve son test puanları arasında anlamlı bir farklılık oluştuğunu göstermiştir.

Cansüngü-Koray ve Bal (2002) çalışmalarını öğrencilerin 1şıłk ve 1şı hı hı ile ilgili kavram yanılgılarını açığa çıkarmak amacıyla yapmışlardır. Öğrencilerin ışıkla ilgili bazı temel kavramlarda yanılgılara sahip olduklarını ve bu kavram yanılgılarının büyük oranda günlük yaşamdaki deneyimlerinden kaynaklandığını bulmuşlardır.

Yeşilyurt ve diğerleri (2005) çalışmalarında; öğrencilerin 1şık konusu hakkındaki düşüncelerini öğrenmek amacıyla yarı yapılandırılmış görüşme tekniğini kullanmışlardır. Araştırmanın sonucunda, öğrencilerin ışık kavramı ile ilgili kavram yanılgılarına sahip oldukları, benzer yaş gruplarının algılamalarının da benzer olduğu bulunmuştur.

\subsection{Araştırmanın Amacı ve Problem Cümlesi}

Kimya alanında yaygın olarak kullanılan 1şık-madde etkileşimine dayalı spektroskopik analiz yöntemlerinin öğretiminde, aktif öğrenme yaklaşımlarından proje tabanlı öğrenme yaklaşımının uygun bir yaklaşım olacağı düşünülmektedir. Proje tabanlı öğrenme yaklaşımına yönelik alan yazın incelendiğinde; bu yaklaşımın öğrencilerin akademik başarısını artırdığı görülmektedir. Ülkemizde proje tabanlı 
öğrenme yaklaşımı ile ilgili yapılan çalışmalar çoğunlukla ilköğretim ve ortaöğretim seviyesinde olup (Atıcı \& Polat, 2010; Ayaz \& Söylemez, 2015; Baran, 2011; İmer, 2008), üniversite lisans öğretimi düzeyinde ise çok fazla çalışmaya rastlanmamıştır (Gülbahar \& Tınmaz, 2006; Sert Çıbık \& İnce Aka, 2016). Bu nedenle üniversite lisans öğretimi düzeyinde yapılacak olan çalışmaların sayısının artması, diğer araştırmacılara da örnek teşkil etmesi açısından önemlidir.

Proje tabanlı öğrenme yaklaşımının, analitik teknikleri tanıma ve analitik cihazların çalışma prensiplerini anlamada, öğrencilere kolaylık sağlayacağı ve etkili olacağı düşünülmüştür (Amarasiriwardena, 2007). Analitik Kimya Laboratuvarında nitel ve nicel analizlerin öğretiminde klasik analizlerin yanı sıra enstrümantal analiz tekniklerinin de kullanılması, öğrencilerin güncel teknolojilere aşina olmaları açısından önem taşımaktadır. $\mathrm{Bu}$ çalışmada "Işık-madde etkileşimine dayanan UV/Görünür bölge spektroskopik analiz yöntemi uygulamaları" konusunun proje tabanlı öğrenme yaklaşımı ile öğretiminde; öğrencilerin grup çalışması ile bilimsel bir araştırma sürecini yaşamaları, bir proje ürünü oluşturmaları, UV/Görünür bölge spektrofotometresi cihazını tanımaları, teorisi hakkında bilgi sahibi olmaları ve spektroskopik analiz yöntemi ile ilgili uygulama yapabilmeleri hedeflenmiştir.

$\mathrm{Bu}$ araştırmanın problem cümlesi; "Işık-madde etkileşimine dayanan UV/Görünür bölge spektroskopik analiz yöntemi uygulamaları" konusunda, proje tabanlı öğrenme yaklaşımının öğrencilerin akademik başarısına etkisi nedir?, alt problem cümleleri ise; "Deney ve kontrol grubu öğrencilerinin ön-test akademik başarı puanları arasında anlamlı bir farklılık var mıdır?", "Deney ve kontrol grubu öğrencilerinin son test akademik başarı puanları arasında anlamlı bir farklılık var mıdır?", "Deney grubu öğrencilerinin ön test ve son test akademik başarı puanları arasında anlamlı bir farklılık var mıdır?" "Kontrol grubu öğrencilerinin ön test ve son test akademik başarı puanları arasında anlamlı bir farklılık var mıdır?" "Deney grubu öğrencilerinin uygulama sürecine yönelik görüşleri nelerdir?”, "Deney grubu öğrencilerinin görüşmelerde konuya yönelik sorulan bilimsel soruyu anlama düzeyleri nedir? ve "Kontrol grubu öğrencilerinin uygulama sürecine yönelik görüşleri nelerdir?, "Kontrol grubu öğrencilerinin görüşmelerde konuya yönelik sorulan bilimsel soruyu anlama düzeyleri nedir?" şeklindedir.

\section{YÖNTEM}

\subsection{Araştırma Deseni}

$\mathrm{Bu}$ araştırmada ön test-son test kontrol gruplu yarı deneysel desen kullanılmıştır (Balcı, 2001; Karasar, 2003). Yarı deneysel desen değişkenlerin arasındaki neden sonuç ilişkisini en iyi açıklayan desenlerden biridir (Fraenkel \& Wallen, 2006). Bu çalışmada, çalışma grubu olarak belirlenen öğrencilere ön bilgi düzeylerini belirlemek amacıyla ön test uygulanmış ve ön test puanlarına göre grup sayıları birbirine eşit olacak şekilde yansız (rastgele) atama ile deney ve kontrol grupları oluşturulmuştur (Christensen, Johnson, \& Turner, 2015).

\section{2. Çalışma Grubu}

$\mathrm{Bu}$ araştırmanın çalışma grubunu, Dokuz Eylül Üniversitesi Kimya Öğretmenliği lisans programında öğrenim gören 2.sınıf öğrencileri $(\mathrm{N}=24)$ oluşturmuştur. Çalışma, 2012-2013 öğretim yılı bahar döneminde gerçekleştirilmiştir. Analitik Kimya Laboratuvar dersini ilk kez alan öğrenciler, rastgele kontrol $(\mathrm{N}=12)$ ve deney $(\mathrm{N}=12)$ grubuna atanmışlardır. "Işık-madde etkileşimine dayanan 
UV/Görünür bölge spektroskopik analiz yöntemi uygulamaları" konusu, deney grubu öğrencilerinde proje tabanlı öğrenme yaklaşımı ile, kontrol grubu öğrencilerinde ise öğretim programına uygun şekilde 6 hafta süresince uygulanmıştır. Uygulama hem deney hem de kontrol grubunda aynı araştırmacılar tarafından yürütülmüştür.

Çalışma, Analitik kimya laboratuvarı dersini ilk kez alan 24 öğrenci ile sınırlıdır. Proje tabanlı öğrenme yaklaşımının uygulanma sürecinde fazla sayıda öğrenci ile çalışılması organizasyon sıkıntısına neden olabilir. Laboratuvar çalışmalarında sınıf içi tartışmaların düzgün organize edilmesi ve projenin dikkatli bir şekilde planlanması, proje tabanlı laboratuvar çalışmalarının başarılı bir şekilde tamamlanabilmesi açısından önem taşımaktadır (Amarasiriwardena, 2007). Bu nedenle çalışma grubundaki öğrenci sayısının çalışma koşulları için uygun olduğu kabul edilmiştir.

\subsection{Veri Toplama Araçları}

Proje tabanlı öğrenme yaklaşımının kimya öğretmen adaylarının akademik başarısına etkisini araştırmak amacıyla 7 tane açık uçlu soru, deney ve kontrol grubu öğrencilerine ön test ve son test olarak uygulanmıştır. Açık-uçlu soruların geçerliği için iki uzman görüşü alınmıştır. Çalışmanın nitel verileri yarı yapılandırılmış görüşmeler ile elde edilmiştir.

2.3.1. Ön-son test: Açık uçlu sorular uygulama öncesi öğrencilerin konuya yönelik ön bilgilerini yoklamak amacıyla ön test olarak uygulanmış, uygulama sonunda aynı sorular öğrencilerin başarılarında ki değişimi görmek amacıyla her iki grup öğrencilerine son test olarak tekrar uygulanmıştır. Açık uçlu soruların ilk 3 sorusu; spektroskopik analiz yöntemlerinin çeşitleri, 1 şı-madde etkileşimi ve spektroskopik analiz yöntemlerine yönelik temel tanımlarla ilgilidir. Diğer 4 soru ise kalibrasyon grafiklerinin oluşturulması, derişimi bilinmeyen maddenin derişiminin spektroskopik yöntemle analizi, spektrofotometrenin temel bileşenleri ve Lambert Beer yasası ile ilgilidir. Ön-Son testte kullanılan 7 açık uçlu soru aşağıda verilmiştir:

1. Aletli analiz yöntemleri hakkında neler söyleyebilirsiniz? Spektroskopik analiz yöntem çeşitleri nelerdir ve hangi amaçlarla kullanılır?

2. Işık-madde etkileşimi konusunda neler söyleyebilirsiniz?

3. Absorpsiyon, emisyon, geçirgenlik, dalga boyu, molar soğurma katsayısı ve frekans kavramlarını açıklayınız.

4. Absorbans-dalga boyu, absorbans derişim grafikleri sizce nasıl oluşturulur ve ne amaçla kullanılır?

5. Derişimi bilinmeyen $\mathrm{KMnO}_{4}$ ya da $\mathrm{K}_{2} \mathrm{Cr}_{2} \mathrm{O}_{7}$ in spektroskopik yöntemle analizi nasıl yapılabilir?

6. Ultraviyole (UV) ve görünür bölge absorpsiyon spektrofotometrelerinin temel bileşenlerini şematik olarak gösteriniz.

7. Lambert- Beer yasası nedir? Lambert-Beer Yasasından sapmaları açıklayınız.

2.3.2. Yarı yapılandırılmış görüşmeler. Yarı yapılandırılmış görüşmeler; gönüllü olarak görüş bildirmek isteyen, deney grubundan 5, kontrol grubundan ise 3 öğrenci olmak üzere 8 öğrenci ile gerçekleştirilmiştir. Görüşmeler her bir öğrenci ile 8-10 dakika kadar sürmüştür. Yarı yapılandırılmış görüşmeler ile deney ve kontrol grubu öğrencilerinin uygulama sürecine yönelik görüşleri belirlenmiştir. Ayrıca 
görüşmeler sırasında öğrencilere uygulama konusuna yönelik bilimsel bir soru da sorularak öğrencilerin anlama düzeyleri belirlenmeye çalışılmıştır. Öğrencilere konuya yönelik olarak " $\mathrm{Mn}^{7+}, \mathrm{Cu}^{2+}$ ya da $\mathrm{Cr}^{6+}$ iyonlarını içeren bir çözeltinin nicel analizinde nasıl bir yol izlersin? şeklinde bir soru sorulmuştur. Ses kayıt cihazı ile görüşmeler kaydedilmiştir.

\subsection{Veri Analizi}

Çalışmada, SPSS programı ve uygun istatistik analizler kullanılarak veriler değerlendirilmiştir. Çalışılacak gruplarda parametrik testlerin kullanılabilmesi için grupların her birinin sayısı en az 30 olmalıdır (Yiğit, 2007). Ayrıca dağılımın normalliğe uygun olması durumunda parametrik testler kullanılır. Dağılımın normal olduğuna yönelik yeterli kanıt yoksa parametrik olmayan testler kullanılmalıdır (Büyüköztürk, 2006). Verilerin normal dağılıma uygunluğunu test etmek için Shapiro-Wilk testi uygulanmış, çarpıklık (skewness) ve basıklık (kurtosis) katsayılarına bakılmıştır. Shapiro-Wilks testinin anlamlılık düzeyi p> .05; çarpıklık ve basıklık katsayıları -1 ve +1 arasında bulunduğu için dağılım normaldir (Büyüköztürk, Çokluk \& Köklü, 2010). Ayrıca mod, ortalama ve ortancanın eşit olması durumunda dağılımın normal olduğu söylenebilir (Ferguson \& Takane, 1989). $\mathrm{Bu}$ çalışmada mod, ortalama ve ortanca değerlerinin birbirinden farklı olması ve herbir alt grubun 15 kişiden az olması nedeniyle non- parametrik testlerin kullanılmasının daha uygun olacağı düşünülmüştür. Açık uçlu sorulara öğrencilerin verdikleri cevaplar kategorize edilerek; cevap tam doğru ise 3, kısmen doğru ise 2, yanlış ise 1 ve soru boş bırakılmışsa 0 puan verilerek puanlandırılmıştır (Başkan Takaoğlu \& Alev, 2015). Ön ve son testten elde edilen akademik başarı puanları, Mann-Whitney U testi ve Wilcoxon işaretli sıralar testi ile analizlenmiştir. Açık uçlu soruların puanlaması iki araştırmacı tarafından belirlenen kategorilere göre puanlandırılmış, analizciler arasındaki güvenirlik düzeyi korelasyon analizi ile belirlenmiştir. Pearson korelasyon katsayıları; ön testler için 0,854 ve son testler için 0,866 olarak bulunmuştur. Korelasyon katsayısının 0,7-1,00 arasında olması analizciler arasında yüksek düzeyde bir ilişki olduğu şeklinde yorumlanmaktadır (Büyüköztürk, 2006).

$\mathrm{Bu}$ çalışmada etki büyüklüğünün hesaplanmasında Cohen's d kullanılmıştır $\left(\mathrm{d}=\frac{\mathrm{z}}{\sqrt{\mathrm{n}}}\right)$. Hesaplamalar sonucunda bulunan $\mathrm{d}$ değeri şu şekilde yorumlanmaktadır. $\mathrm{d} \leq 0,2$ değerleri küçük, $0,2 \leq \mathrm{d} \leq 0,8$ değerleri orta ve $\mathrm{d} \geq 0,8$ değerleri büyük etki boyutu olduğunu gösterir (Cohen, 1988; Şahin \& Kargın, 2013).

Yarı yapılandırılmış görüşmelerin analizi ise içerik analizi ile gerçekleştirilmiştir. Yarı yapılandırılmış görüşmelerin ses kayıtları yazıya dökülmüş, kod ve temalar iki araştırmacı tarafından bağımsız olarak belirlenmiştir. İki araştırmacı arasındaki kodlayıcı güvenirliğini belirlemek için ise uyuşum yüzdesi $\mathrm{P}=(\mathrm{Na} / \mathrm{Na}+\mathrm{Nd}) .100$ ( $\mathrm{P}$ : uyuşum yüzdesi, $\mathrm{Na}$ : uyuşum miktarı, $\mathrm{Nd}$ : uyuşmazlık miktarı) formülü ile hesaplanmıştır (Türnüklü, 2000). Uyuşum yüzdesi \% 90 olarak bulunmuştur. Bu değer güvenilir olarak kabul edilmektedir (Yıldırım \& Şimşek, 2006). Çalışmada kullanılan istatistiksel veri analizlerinde anlamlılık düzeyi 0,05 olarak kabul edilmiştir.

\subsection{Uygulama Süreci}

Deney grubu öğrencileri ile;

Proje tabanlı öğrenme yaklaşımı uygulaması 6 haftalık süreçte gerçekleştirilmiştir. Uygulama öncesi deney grubu öğrencilerine proje tabanlı 
öğrenme yöntemi ve poster hazırlama konusunda araştırmacılar tarafından bilgilendirme sunumu yapılmıştır. Uygulama için öğrenciler 3'er kişiden oluşan 4 gruba ayrılmıştır $(\mathrm{N}=12)$. Öğrencilere $\mathrm{UV} / \mathrm{Görünür} \mathrm{bölge} \mathrm{spektrofotometrik} \mathrm{analiz}$ uygulamalarına yönelik aşağıdaki proje konuları verilmiştir:

1. Grup: UV/GB spektrofotometresi ile bakırın nicel analizi

2. Grup: UV/GB spektrofotometresi ile demirin nicel analizi

3. Grup: UV/GB spektrofotometresi ile mangan ve kromun nicel analizi

4. Grup: UV/GB spektrofotometresi ile $\mathrm{MnO}_{4}^{-}$ve $\mathrm{Cr}_{2} \mathrm{O}_{7}^{2-}$ karışımının analizi

Öğrencilere proje konuları ve nasıl bir yol izlemeleri gerektiğine yönelik genel bir açıklama yapılmıştır. Öğrencilerin proje konuları ile ilgili uygun çözüme ulaşabilmeleri için, "Işı1k-madde etkileşimine dayanan UV/Görünür bölge spektroskopik analiz yöntemi uygulamaları" konusu 4 alt konuya ayrılmıştır. Her bir grubun belirlenen alt konular ve proje konuları ile ilgili araştırma yapmaları istenmiş ve kendilerine araştırma için süre verilmiştir.

1. Alt konu: Işık ve madde etkileşimi temel kavramlar

2. Alt konu: Spektrofotometre cihazı bileşenleri ve çalışma prensibi,

3. Alt konu: Lambert Beer Yasası ve bu yasadan sapmalar

4. Alt konu: Kalibrasyon grafiğgi oluşturma ve UV/GB spektrofotometresi ile nicel analizler

Öğrenciler kendilerine verilen araştırma süresi sonunda alt konularla ilgili buldukları bilgileri sınıf ortamında sunarak birbirleriyle paylaşmışlardır. Sunumların ardından her bir grup kendi içerisinde tartışarak, proje konularına yönelik çözüm ve deneysel bir tasarım oluşturmaya çalışmışlardır. Gruplara tartışma sürecinde araştırmacılar yönlendirici sorularla rehberlik etmiştir. Her bir grup proje konusuna yönelik çözümlerini belirlemiş ve her bir grubun önerdiği deneysel tasarım tahtaya yazılmıştır. Önerilen deneysel tasarımlar ile ilgili deney grubu öğrencilerinin hepsi görüş bildirmiş, araştırmacıların rehberliğinde gerekli yönlendirmelerle en uygun deneysel tasarımlar oluşturulmuştur. Laboratuvarda deneylerin yapılma süreci öncesinde, öğrenciler laboratuvar güvenlik önlemleri ile ilgili bilgilendirilmiştir. Her bir gruptan seçilen 1'er öğrenci temsilcisi laboratuvarda güvenliği sağlamak ve cihazla çalışırken dikkat etmeleri gereken hususları arkadaşlarına hatırlatmak üzere görevlendirilmiştir. Gruplar proje konuları ile ilgili çözeltileri hazırlamış, belirledikleri deneysel tasarım doğrultusunda analizleri gerçekleştirmiş, ilgili grafik ve hesaplamaları yaparak rapor haline getirmişlerdir. $\mathrm{Bu}$ işlemler sırasında araştırmacılar öğrencilere rehberlik etmişlerdir. Deney sonrası öğrencilere poster sunumlarını hazırlamaları için süre verilmiş, öğrenciler posterlerini hazırlayarak sınıfta birbirlerine sunmuşlardır. Proje tabanlı öğrenme yaklaşımı uygulama süreci Tablo 1'de ve öğrencilerin hazırlamış oldukları posterlerin bazıları örnek olarak Ek 1 'de verilmiştir. 
Tablo 1. Proje tabanlı öğrenme yaklaşımı uygulama süreci

\begin{tabular}{ll}
\hline İşlem Basamakları & Süre \\
\hline & \\
Bilgilendirme sunumu ve grupların oluşturulması & 2 ders saati \\
Öğrencilerin kendilerine verilen araştırma konularını araştırmaları & 5 gün (Okul dışında) \\
Araştırma konularının sınıfta sunulması & 4 ders saati \\
Oluşturulan yeni uzman grupların tartışıp deney taslağı oluşturması & 4 ders saati \\
Laboratuvarda güvenlik önlemlerinin anlatılması & 1 ders saati \\
Çözelti hazırlanması ve öğrenci gruplarının proje konuları ile ilgili & \\
analizleri gerçekleştirmesi & 4 ders saati \\
Poster sunumları & 2 ders saati \\
\hline
\end{tabular}

Kontrol grubu öğrencileri ile;

Kontrol grubu öğrencileri ile "Iş1k-madde etkileşimine dayanan UV/Görünür bölge spektroskopik analiz yöntemi uygulamaları” konusu öğretim programına uygun olarak aynı araştırmacılar tarafından işlenmiştir. Laboratuvar uygulaması öncesi, deney grubu öğrencilerine dağıtılan alt konu başlıkları olan; Işık ve madde etkileşimi temel kavramlar, Spektrofotometre cihazı bileşenleri ve çalışma prensibi, Lambert Beer Yasası ve bu yasadan sapmalar, Kalibrasyon grafiği oluşturma ve UV/GB spektrofotometresi ile nicel analizler eşit ders saati süresince kontrol grubu öğrencilerine anlatılmıştır. Konu anlatımında power point sunum, düz anlatım ve soru-cevap teknikleri kullanılmıştır. Laboratuvar öncesi kontrol grubu öğrencilerine de laboratuvarda uyulması gereken güvenlik önlemleri anlatılmıştır. Konuya yönelik laboratuvar uygulaması için; öğrenciler 3'er kişiden oluşan 4 gruba ayrılmış birer öğrenci grup temsilcisi olarak seçilmiştir. Temsilci öğrenciler cihazın kullanımı ve genel düzenden sorumlu olmuşlardır. Konuya yönelik yapılan spektrofotometrik analizler ile ilgili deneyler, deney grubu öğrencileri ile eşit ders saati sürecinde gerçekleştirilmiştir.

\section{BULGULAR}

\subsection{Deney ve Kontrol Grubu Öğrencilerinin Ön Test-Son Test Akademik Başarı Puanlarının Mann-Whitney U ve Wilcoxon İşaretli Sıralar Testi Sonuçları}

Deney ve kontrol grubu öğrencilerinin ön test ve son test akademik başarı puanları Mann-Whitney U ve Wilcoxon İşaretli Sıralar Testi ile analiz edilmiş ve analiz sonuçları Tablo 2-4'de verilmiştir.

Tablo 2. Deney ve kontrol grubu öğrencilerinin ön test akademik başarı puanlarının Mann- Whitney U Testi

\begin{tabular}{lcccccc}
\hline Grup & $\mathbf{N}$ & Sira ortalaması & Sira toplamı & $\mathbf{U}$ & $\mathbf{z}$ & $\mathbf{p}$ \\
\hline Deney & 12 & 12,79 & 152 & 68.50 & .208 & .835 \\
\hline Kontrol & 12 & 12,21 & 148 & & & \\
\hline
\end{tabular}

Tablo 2 incelendiğinde; deney ve kontrol grubu öğrencilerinin ön test akademik başarı puanları arasında anlamlı bir fark olmadığı ve grupların birbirine denk kabul edilebileceği görülmektedir ( $\mathrm{p}>.05)$. 
Tablo 3. Deney ve kontrol grubu öğrencilerinin son test akademik başarı puanlarının Mann- Whitney U Testi

\begin{tabular}{lcccccc}
\hline Grup & $\mathbf{N}$ & Sira Ortalaması & $\begin{array}{c}\text { Sira } \\
\text { Toplamı }\end{array}$ & $\mathbf{U}$ & $\mathbf{z}$ & $\mathbf{p}$ \\
\hline Deney & 12 & 17.08 & 205 & 17 & 3.90 & .001 \\
\hline Kontrol & 12 & 7.92 & 95 & & & \\
\hline
\end{tabular}

Tablo 3 incelendiğinde ise; deney ve kontrol grubu öğrencilerinin son test akademik başarı puanları kıyaslandığında deney grubu öğrencilerinin lehine anlamlı bir fark olduğu gözlenmektedir $(\mathrm{p}<.05)$. Mann-Whitney U Testi analizi sonuçlarına göre; "Işık-madde etkileşimine dayanan UV/Görünür bölge spektroskopik analiz yöntemi uygulamaları" konusunun öğretiminde, proje tabanlı öğrenme yaklaşımının akademik başarıyı artırmada daha etkili olduğu söylenebilir.

Deney ve kontrol grubu öğrencilerinin uygulama öncesi ve sonrası grup içi akademik başarılarının farklılık gösterip göstermediğine ilişkin Wilcoxon işaretli sıralar testi sonuçları Tablo 4'te verilmiştir.

Tablo 4. Deney ve kontrol grubu ön-test son-test akademik başarı puanlarının Wilcoxon İşaretli Sıralar Testi

\begin{tabular}{lcccccc}
\hline Grup & $\mathbf{N}$ & $\begin{array}{c}\text { Ön Test } \\
\text { Medyan } \\
\text { (Min.-Max.) }\end{array}$ & $\begin{array}{c}\text { Medyan } \\
\text { (Min.-Max.) }\end{array}$ & $\mathbf{z}$ & $\mathbf{p}$ & $\mathbf{d}$ \\
\hline Deney & 12 & $4(0-8)$ & $12(8-20)$ & 3.065 & .002 & 0.88 \\
\hline Kontrol & 12 & $4.5(0-6)$ & $7(2-12)$ & 2.556 & .011 & 0.74 \\
\hline
\end{tabular}

Tablo 4 incelendiğinde; proje tabanlı öğrenme yaklaşımına göre yapılan laboratuvar uygulaması sonucunda deney grubu öğrencilerinin ön-son test puanları arasında anlamlı bir fark olduğu gözlenmektedir $(\mathrm{z}=3.065, \mathrm{p}<.05, \mathrm{~d}=0.88)$. Elde edilen veriler öğretim programına uygun olarak yürütülen laboratuvar dersinde de kontrol grubu öğrencilerinin ön-son test puanları arasında anlamlı bir fark olduğunu göstermektedir $(\mathrm{z}=2.556, \mathrm{p}<.05, \mathrm{~d}=0.74)$. Ancak deney grubu öğrencilerinin medyan değerinin kontrol grubu öğrencilerine göre daha yüksek olması nedeniyle, uygulanan proje tabanlı öğrenme yaklaşımının öğrencilerin akademik başarılarını arttırmada daha etkili olduğu şeklinde yorumlanabilir. Ayrıca etki büyüklüğü $d$ değeri incelendiğinde de; proje tabanlı öğrenme yaklaşımının etki büyüklüğünün kontrol grubuna kıyasla daha büyük olduğu söylenebilir.

\subsection{Deney ve Kontrol Grubu Öğrencilerinin Açık Uçlu Sorulara Verdikleri Cevapların İçerik Analizi}

Deney ve kontrol grubu öğrencilerinin ön ve son testte açık uçlu sorulara verdikleri cevapların kategorize edilerek elde edilen içerik analizi sonuçları Tablo 5 ve 6 'da verilmiştir. 
Tablo 5. Deney ve kontrol grubu öğrencilerinin açık uçlu sorulara ön testte verdikleri cevapların içerik analizi

\begin{tabular}{|c|c|c|c|c|c|c|c|c|c|c|c|c|c|c|c|c|}
\hline \multirow{3}{*}{$\begin{array}{l}\text { Soru } \\
\text { No }\end{array}$} & \multicolumn{10}{|c|}{$\begin{array}{c}\text { KATEGORILER } \\
\text { Deney Grubu (N=12) }\end{array}$} & \multicolumn{6}{|c|}{$\begin{array}{c}\text { KATEGORİLER } \\
\text { Kontrol Grubu }(\mathbf{N}=12)\end{array}$} \\
\hline & \multicolumn{2}{|c|}{$\begin{array}{l}\text { Tam } \\
\text { Doğru } \\
\text { (TD) }\end{array}$} & \multicolumn{2}{|c|}{$\begin{array}{c}\text { Kısmen } \\
\text { Doğru } \\
\text { (KD) }\end{array}$} & \multicolumn{2}{|c|}{$\begin{array}{c}\text { Yanlış } \\
(\mathbf{Y})\end{array}$} & \multicolumn{2}{|c|}{$\begin{array}{l}\text { Boş } \\
\text { (B) }\end{array}$} & \multicolumn{2}{|c|}{$\begin{array}{c}\text { Tam } \\
\text { Doğru } \\
\text { (TD) }\end{array}$} & \multicolumn{2}{|c|}{$\begin{array}{c}\text { Kismen } \\
\text { Doğru } \\
\text { (KD) }\end{array}$} & \multicolumn{2}{|c|}{$\begin{array}{c}\text { Yanlış } \\
(\mathbf{Y})\end{array}$} & \multicolumn{2}{|c|}{$\begin{array}{l}\text { Boş } \\
\text { (B) }\end{array}$} \\
\hline & $\mathbf{f}$ & $\%$ & f & $\%$ & f & $\%$ & $\mathbf{f}$ & $\%$ & $\mathbf{f}$ & $\%$ & $\mathbf{f}$ & $\%$ & $\mathbf{f}$ & $\%$ & f & $\%$ \\
\hline 1 & - & 0 & 8 & 67 & - & 0 & 4 & 33 & - & 0 & 5 & 42 & 4 & 33 & 3 & 25 \\
\hline 2 & - & 0 & 4 & 33 & - & 0 & 8 & 67 & - & 0 & 4 & 33 & 2 & 17 & 6 & 50 \\
\hline 3 & - & 0 & 8 & 67 & - & 0 & 4 & 33 & - & 0 & 6 & 50 & 2 & 17 & 4 & 33 \\
\hline 4 & - & 0 & 2 & 17 & 1 & 8 & 9 & 75 & - & 0 & - & 0 & - & 0 & 12 & 100 \\
\hline 5 & - & 0 & - & 0 & - & 0 & 12 & 100 & - & 0 & - & 0 & - & 0 & 12 & 100 \\
\hline 6 & - & 0 & - & 0 & - & 0 & 12 & 100 & - & 0 & - & 0 & - & 0 & 12 & 100 \\
\hline 7 & - & 0 & - & 0 & - & 0 & 12 & 100 & - & 0 & - & 0 & - & 0 & 12 & 100 \\
\hline
\end{tabular}

Tablo 5 incelendiğinde; hem deney hem de kontrol grubu öğrencilerinin ön testte soruların hiçbirisine tam doğru cevap veremedikleri görülmektedir. Öğrenciler 1,2 ve 3 no'lu sorulara kısmen doğru cevaplar verebilirken, uygulamaya yönelik olan 4.soruyu deney grubu öğrencilerinden sadece \%17'sinin kısmen doğru cevaplayabildiği, 5,6 ve 7 . soruları ise öğrencilerin tamamının boş bıraktığ görülmektedir.

Tablo 6. Deney ve kontrol grubu öğrencilerinin açık uçlu sorulara son testte verdikleri cevapların içerik analizi

KATEGORILER

Deney Grubu $(\mathrm{N}=12)$

\section{KATEGORILER}

Kontrol Grubu (N=12)

\begin{tabular}{|c|c|c|c|c|c|c|c|c|c|c|c|c|c|c|c|c|}
\hline \multirow[t]{2}{*}{$\begin{array}{c}\text { Soru } \\
\text { No }\end{array}$} & \multicolumn{2}{|c|}{$\begin{array}{c}\text { Tam } \\
\text { Doğru } \\
\text { (TD) }\end{array}$} & \multicolumn{2}{|c|}{$\begin{array}{c}\text { Kismen } \\
\text { Doğru } \\
\text { (KD) }\end{array}$} & \multicolumn{2}{|c|}{$\begin{array}{c}\text { Yanlış } \\
(\mathbf{Y})\end{array}$} & \multicolumn{2}{|c|}{$\begin{array}{l}\text { Boş } \\
\text { (B) }\end{array}$} & \multicolumn{2}{|c|}{$\begin{array}{c}\text { Tam } \\
\text { Doğru } \\
\text { (TD) }\end{array}$} & \multicolumn{2}{|c|}{$\begin{array}{c}\text { Kismen } \\
\text { Doğru } \\
(\text { KD) }\end{array}$} & \multicolumn{2}{|c|}{$\begin{array}{c}\text { Yanlış } \\
(\mathbf{Y})\end{array}$} & \multicolumn{2}{|c|}{$\begin{array}{l}\text { Boş } \\
\text { (B) }\end{array}$} \\
\hline & $\mathbf{f}$ & $\%$ & $\mathbf{f}$ & $\%$ & $\mathbf{f}$ & $\%$ & $\mathbf{f}$ & $\%$ & $\overline{\mathbf{f}}$ & $\%$ & f & $\%$ & f & $\%$ & $\mathbf{f}$ & $\%$ \\
\hline 1 & 4 & 33 & 3 & 25 & - & 0 & 5 & 42 & - & 0 & 2 & 17 & 3 & 25 & 7 & 58 \\
\hline 2 & - & 0 & 5 & 42 & - & 0 & 7 & 78 & - & 0 & 7 & 78 & 2 & 22 & - & 0 \\
\hline 3 & 4 & 33 & 8 & 67 & - & 0 & - & 0 & - & 0 & 10 & 83 & 1 & 8 & 1 & 8 \\
\hline 4 & 2 & 17 & 9 & 75 & - & 0 & 1 & 8 & - & 0 & 6 & 50 & - & 0 & 6 & 50 \\
\hline 5 & 4 & 33 & 4 & 33 & - & 0 & 4 & 33 & - & 0 & 1 & 8 & 1 & 8 & $\begin{array}{l}1 \\
0\end{array}$ & 83 \\
\hline 6 & 7 & 58 & 1 & 8 & - & 0 & 4 & 33 & 3 & 25 & - & 0 & - & 0 & 9 & 75 \\
\hline 7 & 5 & 42 & 7 & 58 & - & 0 & - & 0 & - & 0 & 10 & 83 & - & 0 & 2 & 17 \\
\hline
\end{tabular}

Tablo 6 incelendiğinde; Deney grubu öğrencilerinin son testte tam doğru ve kısmen doğru cevaplarının yüzdelerinin kontrol grubu öğrencilerine kıyasla daha yüksek olduğu görülmektedir. Deney grubu öğrencilerinin özellikle laboratuvar uygulamalarına yönelik sorularda daha yüksek oranda tam doğru cevap verdikleri görülmektedir.

Elde edilen veriler değerlendirildiğinde; Ön testte her iki grup öğrencisinden 1.soruya tam doğru cevap veren hiç kimse olmadiğı, son testte ise bu soruya deney grubu öğrencilerinin \%33'ünün tam doğru cevap verebildiği, kontrol grubu öğrencilerinden ise hiçbirisinin tam doğru cevaplayamadığ sonucuna ulaş1lmıştır. 2. soru ile ilgili sonuçlar incelendiğinde ise; deney ve kontrol grubu öğrencilerinin ön ve son testin her ikisinde de bu soruya tam doğru cevap veremedikleri görülmektedir. 3 . soruda ise ön testte her iki grup öğrencilerinin tam doğru cevapları bulunmazken, son 
testte sadece deney grubu öğrencilerinden \%33'ünün tam doğru cevap verebildikleri gözlenmiştir. "Aletli analiz yöntemleri hakkında neler söyleyebilirsiniz? Spektroskopik analiz yöntem çeşitleri nelerdir ve hangi amaçlarla kullanılır?" "Işıkmadde etkileşimi konusunda neler söyleyebilirsiniz?" "Absorpsiyon, emisyon, geçirgenlik, dalga boyu, molar soğurma katsayısı ve frekans kavramlarını açıklayınız" şeklinde konunun teorisine yönelik sorulan bu üç soru için hem deney hem de kontrol grubu öğrencilerinin son testte de düşük oranda tam doğru cevap verebilmiş olmaları, öğrencilerin teorik bilgi kısmında hala bilgi eksikliklerinin bulunduğu şeklinde yorumlanabilir.

Deney ve kontrol grubundaki öğrencilerin konunun deneysel tasarım ve laboratuvar uygulamalarına yönelik olan $4.5,6$ ve 7 . sorulara vermiş oldukları cevaplara yönelik yorumlar ve öğrenci cevaplarından bazı örnekler aşağıda sunulmuştur:

"Absorbans-dalga boyu, absorbans-derişim grafikleri sizce nasıl oluşturulur ve ne amaçla kullanılır?" şeklinde ki 4. soruya öğrencilerin verdikleri cevaplar incelendiğinde; ön testte deney grubundan öğrencilerin sadece yüzde 17'sinin soruyu kısmen doğru cevaplayabildiği, kontrol grubunda ise öğrencilerin tamamının soruyu boş bıraktığı görülmektedir. Son testte ise; deney grubu öğrencilerinin yüzde 17'sinin soruyu tam doğru, yüzde $75^{\prime}$ inin ise kısmen doğru cevapladıkları görülmektedir. Kontrol grubu öğrencilerin son test sonuçlarında ise; öğrencilerin tam doğru cevap veremedikleri, yüzde 50'sinin kısmen doğru cevaplayabildikleri belirlenmiştir. Deney grubu öğrencilerinden son testte 4 . soruya tam doğru ve kısmen doğru cevap veren öğrencilerin bazılarının cevapları ile kontrol grubu öğrencilerinden bu soruya kısmen doğru cevap veren bir öğrenci cevabı örnek olarak Tablo 7'de verilmiştir.

Tablo 7. Son testte 4. soruya verilen cevap örnekleri

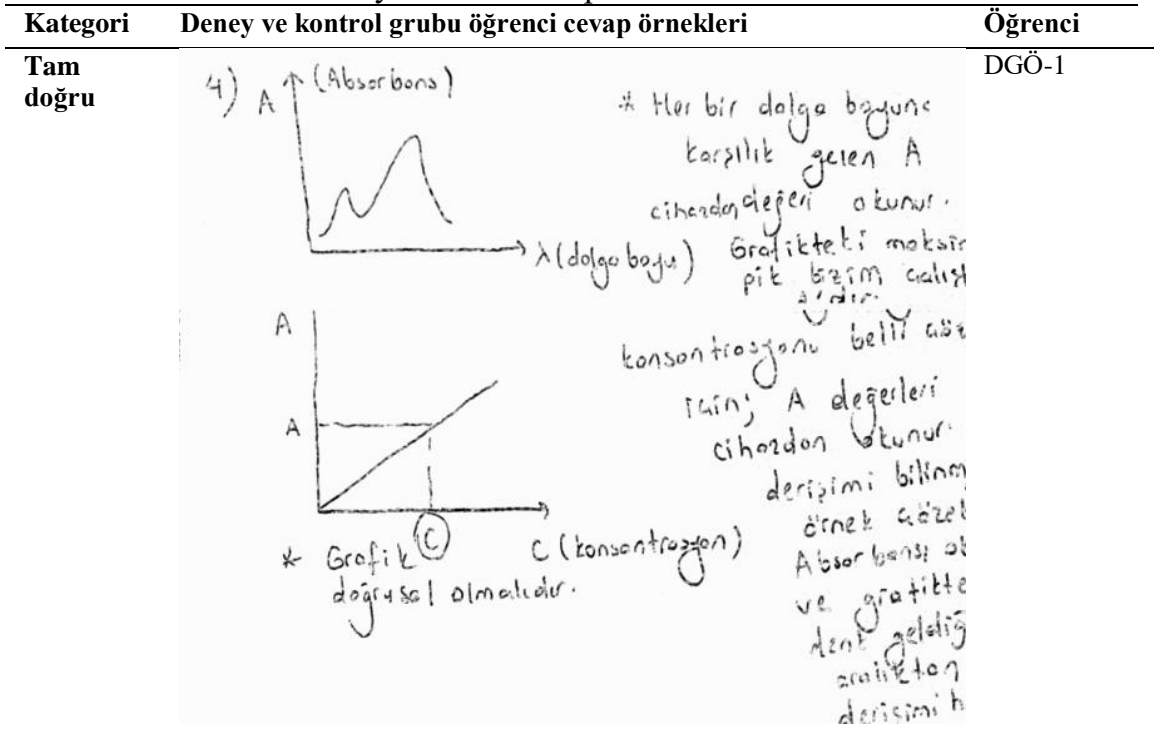




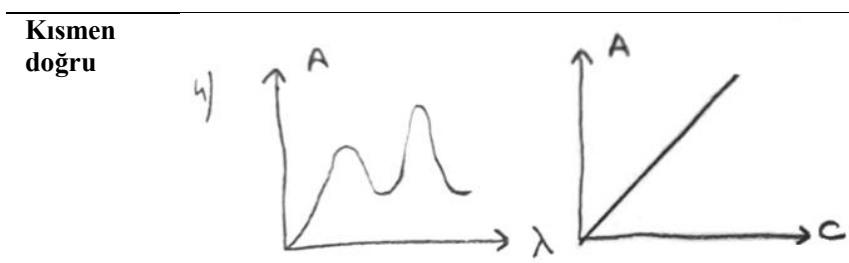

DGÖ-3

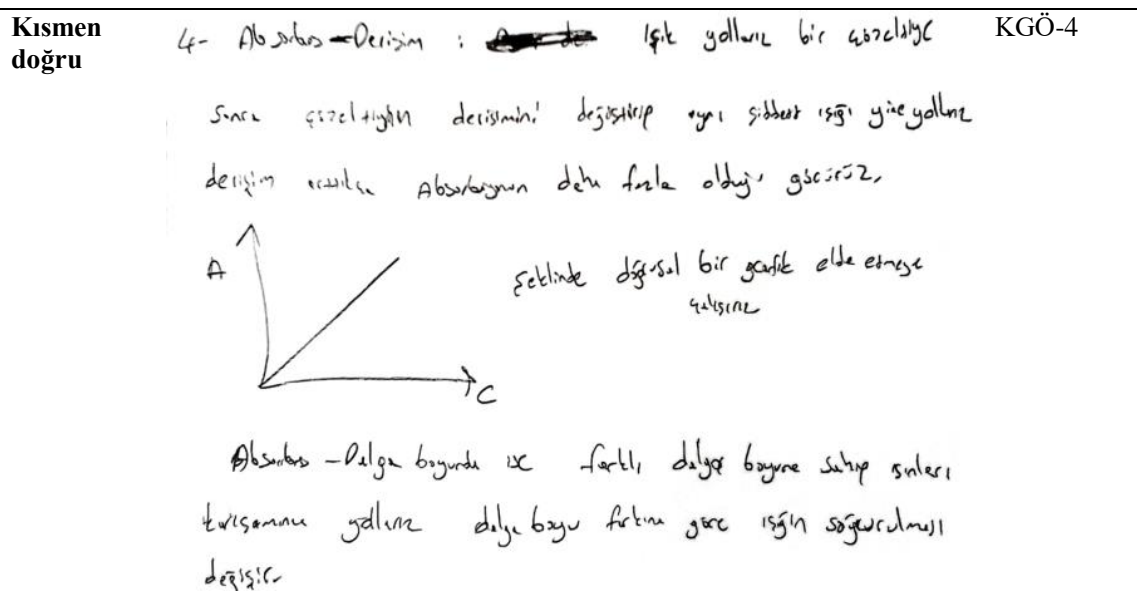

“Derişimi bilinmeyen $\mathrm{KMnO}_{4}$ ya da $\mathrm{K}_{2} \mathrm{Cr}_{2} \mathrm{O}_{7}$ '1n spektroskopik yöntemle analizi nasıl yapılabilir?" şeklinde sorulan 5. soruda ön testte deney ve kontrol grubu öğrencilerinin tamamının bu soruyu cevaplayamadıkları, son testte ise deney grubu öğrencilerinin \%33'ünün tam doğru ve \%33'ünün kısmen doğru cevap verebildikleri görülmektedir. Kontrol grubu öğrencilerinin ise tam doğru cevap veremedikleri, sadece \%8'inin kısmen doğru cevap verebildiği belirlenmiştir. 5. soruya yönelik deney ve kontrol grubu son test öğrenci cevaplarından bazıları Tablo 8'de görülmektedir. 
Tablo 8. Son testte 5. soruya verilen cevap örnekleri

\begin{tabular}{|c|c|c|}
\hline Kategori & Deney ve kontrol grubu öğrenci cevap örnekleri & Öğrenci \\
\hline Tam doğru & 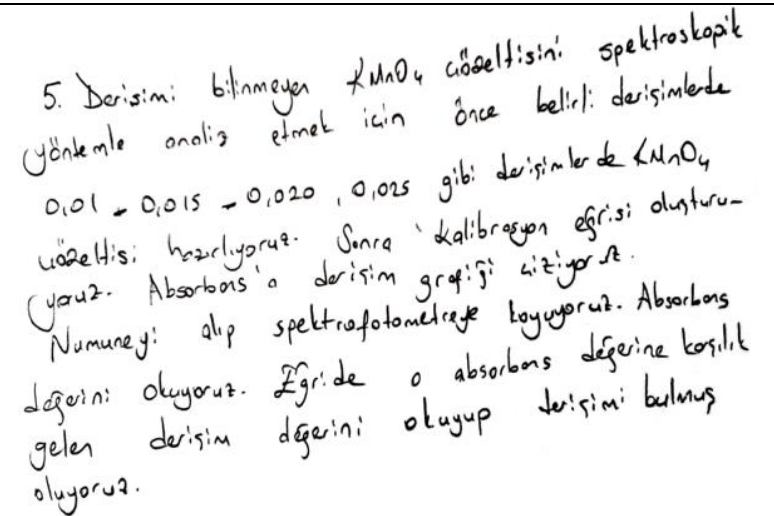 & DGÖ-4 \\
\hline $\begin{array}{l}\text { Kısmen } \\
\text { doğru }\end{array}$ & $\begin{array}{l}\text { 5) } \mathrm{KmnO}_{4} \times \mathrm{K}_{2} \mathrm{Cr}_{2} \mathrm{O}_{7} \text { spektroskopic yönteme max dojaa } \\
\text { baju whinur. Onoktadaki absabsigenubulunur. Ye nesaplona } \\
\text { yapilur derisim bulunur, }\end{array}$ & DGÖ-10 \\
\hline $\begin{array}{l}\text { Kısmen } \\
\text { doğru }\end{array}$ & 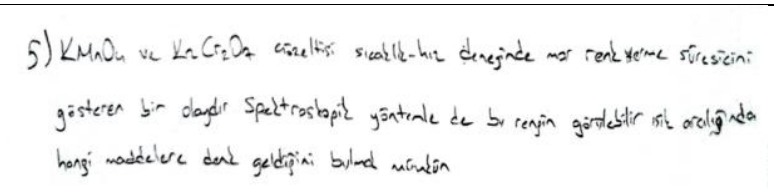 & KGÖ-1 \\
\hline
\end{tabular}

"Ultraviyole (UV) ve görünür bölge absorpsiyon spektrofotometrelerinin temel bileşenlerini şematik olarak gösteriniz" şeklinde sorulan 6. soruya, ön testte her iki grup öğrencisi de cevap verememiştir. Son test sonuçları incelendiğinde ise; deney grubu öğrencilerinin bu soruya $\% 58$ oranında tam doğru ve $\% 8$ oranında kısmen doğru cevap verdikleri, kontrol grubu öğrencilerinde ise sadece $\% 25$ oranında tam doğru cevaplarının bulunduğu belirlenmiştir. 6 . soruya yönelik deney ve kontrol grubu son test öğrenci cevaplarından bazıları Tablo 9'da görülmektedir. 
Tablo 9. Son testte 6. soruya verilen cevap örnekleri

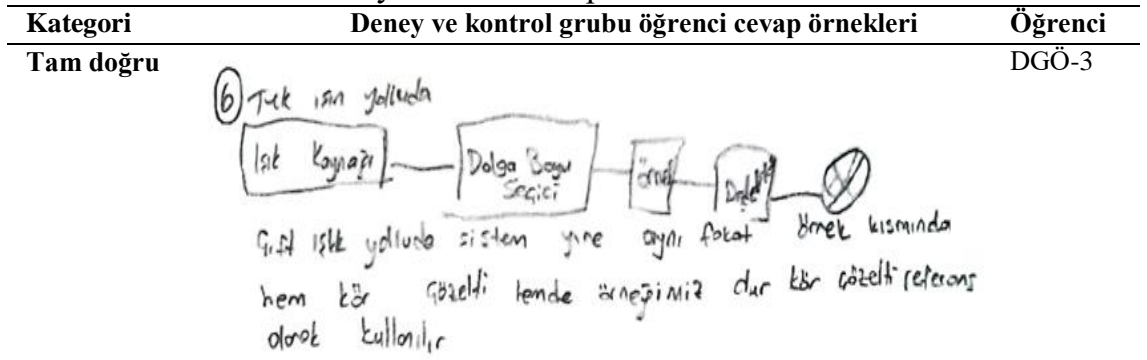

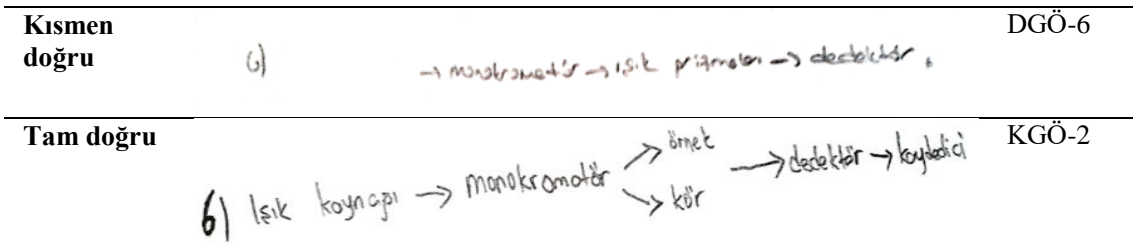

"Lambert- Beer yasası nedir? Lambert-Beer Yasasından sapmaları açıklayınız" şeklinde sorulan 7.soru ile ilgili veriler incelendiğinde; ön testte her iki grup öğrencisinin de soruyu cevaplayamadığı görülmektedir. Son test sonuçlarında ise; deney grubu öğrencilerinin \%42'sinin soruyu tam doğru ve \%58'inin ise kısmen doğru cevapladığ1, kontrol grubu öğrencilerinin tam doğru cevabının olmadığı ve \%83'ünün kısmen doğru cevap verebildiği gözlenmiştir. 7. Soruya yönelik deney ve kontrol grubu son test öğrenci cevaplarından bazıları Tablo 10'da verilmiştir.

Tablo 10. Son testte 7. soruya verilen cevap örnekleri

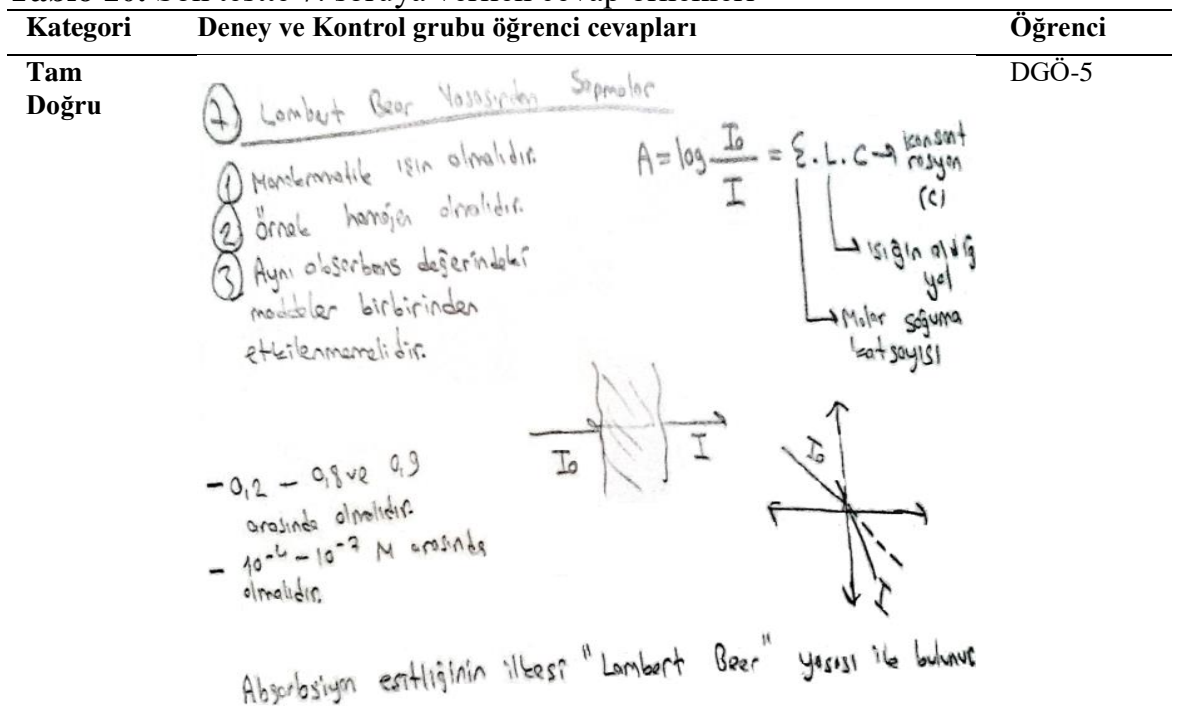




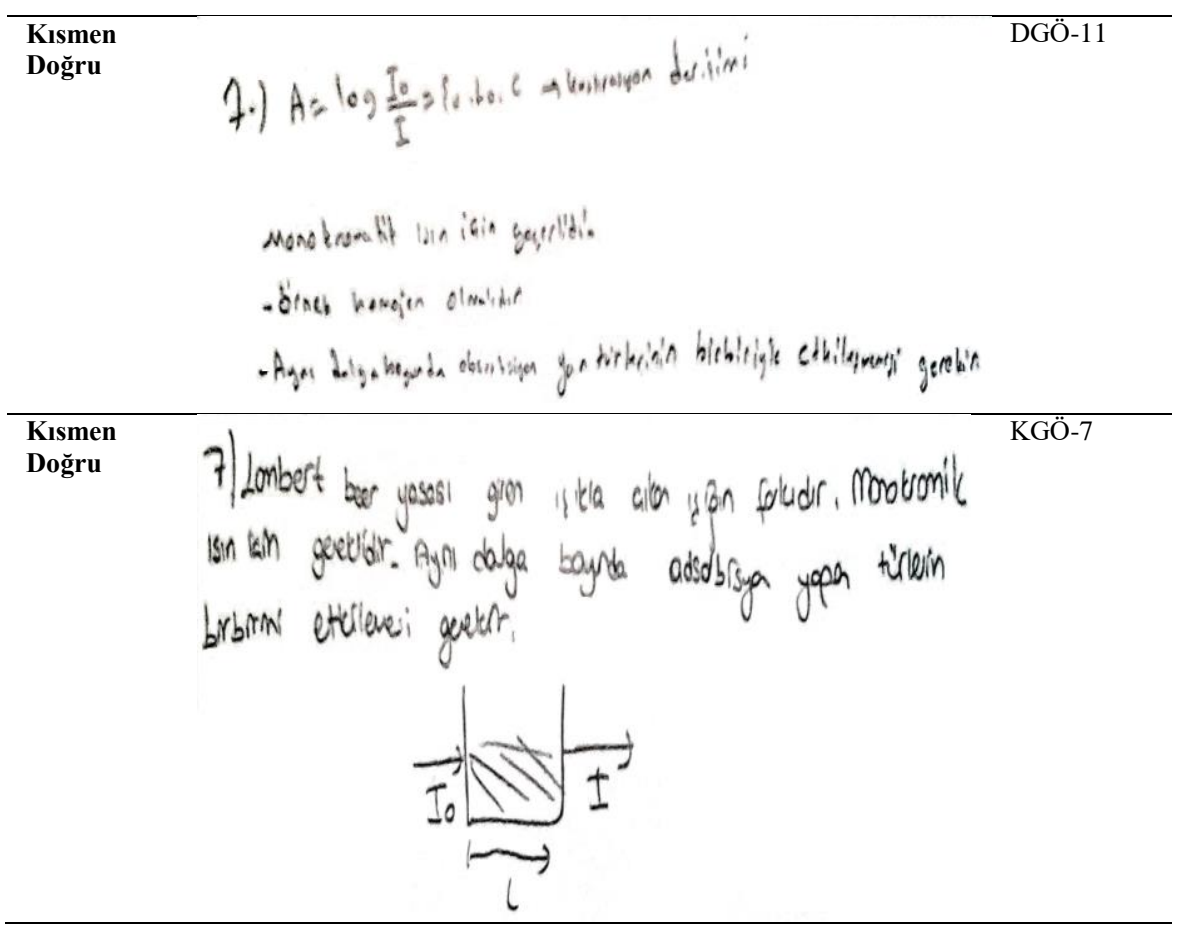

$4,5,6$ ve 7 . sorular ile ilgili elde edilen veriler genel olarak değerlendirildiğinde; spektrofotometre ve laboratuvar uygulamalarına yönelik sorulan bu sorularda deney ve kontrol grubu öğrencilerinin ön testte çoğunlukla cevap veremediği, son testte ise cevap verme yüzdelerinin arttığı görülmektedir. Ancak, deney grubu öğrencilerinin cevap verme yüzdelerindeki artış oranının kontrol grubu öğrencilerine kıyasla daha yüksek olduğu gözlenmiştir. Deney grubu öğrencilerinin laboratuvar uygulamasına yönelik bu sorularda daha başarılı olmalarının nedeninin; proje tabanlı öğrenme yaklaşımı ile öğrencilerin araştırma yapmalarına olanak sağlanmış olmasının ve grup içerisinde tartışarak deney tasarımlarını kendilerinin oluşturmuş olmalarının etkisine bağlı olduğu düşünülebilir.

\subsection{Yarı Yapılandırılmış Görüşmelerden Elde Edilen Bulgular}

Yarı yapılandırılmış görüşmelerin içerik analizi sonucu elde edilen temalar ile ilgili veriler Tablo $11-14$ 'te verilmiştir. Tablo 11'de deney grubu öğrencilerinin uygulama sürecine yönelik olumlu görüşleri görülmektedir. 
Tablo 11. Deney grubu öğrencilerinin yarı yapılandırılmış görüşmelerinin içerik analizi ve olumlu ifadeleri

\begin{tabular}{|c|c|c|}
\hline Tema & Olumlu öğrenci ifadesi & Frekans (f) \\
\hline Yöntem & $\begin{array}{l}\text { "Ben bu yöntemin çok yararlı oldŭ̆unu düşünüyorum. PTÖ sayesinde } \\
\text { bir cihaz kullanmış oldum” (DGÖ-1) } \\
\text { “Proje tabanlı ögrenme faydall. Çünkü aşama aşama yapıyoruz. } \\
\text { Herşeyi ince ayrıntısına kadar inceliyoruz. Yaptığımız deneyi ya da } \\
\text { projeyi çok iyi anlayarak yapıyoruz" (DGÖ-4) }\end{array}$ & 5 \\
\hline $\begin{array}{l}\text { Akılda } \\
\text { Kalıcılık }\end{array}$ & $\begin{array}{l}\text { "Öğrendiğimiz konular akılda daha kalıcı oluyor. Kendimiz birşeyleri } \\
\text { araştırıp deney yapıp sonuca ulaştığımız için daha iyi akılda kaldığını } \\
\text { düşünüyorum" (DGÖ-3) } \\
\text { "Olumlu yanı akılda kalıcı olmasını sağlıyor" (DGÖ-2) }\end{array}$ & 4 \\
\hline $\begin{array}{l}\text { Grup } \\
\text { Çalışması }\end{array}$ & $\begin{array}{l}\text { "Herkes üzerine düşeni yaptı. Konu dağılımı yaptık. Herkes farklı } \\
\text { kaynaklardan bilgi topladı. İş bölümü yaptık. İş dağllım yaptık. } \\
\text { Beraber güzel bir çalışma yaptık. Bizim anlamadı̆̆ımız yeri diğer } \\
\text { arkadaşımız anladıysa o tamamladı. Herkes birbirinin eksiğini } \\
\text { tamamladı güzel oldu" (DGÖ-4) }\end{array}$ & 4 \\
\hline İletişim & $\begin{array}{l}\text { "Bir kere kişiler arası iletişim ve paylaşımı arttırıyor. Ödev aldığın } \\
\text { zaman iletişiminin fazla olmadığ bir arkadaşınla daha çok konuşup } \\
\text { tartışabiliyorsun" (DGÖ-2) }\end{array}$ & 3 \\
\hline
\end{tabular}

Elde edilen veriler incelendiğinde; deney grubu öğrencilerinin proje tabanlı öğrenmeyi yararlı buldukları, grup çalışmasını yararlı buldukları, araştırma yapmaları ve sonrasında deneyi yapmış olmalarının bilginin akıda kalıcı olmasını sağladığını ve yaptıkları deneyin daha akılda kalıcı olduğunu ifade ettikleri görülmüştür.

Tablo 12'de deney grubu öğrencilerinin uygulama sürecine yönelik olumsuz görüşleri görülmektedir.

Tablo 12. Deney grubu öğrencilerinin yarı yapılandırılmış görüşmelerinin içerik analizi ve olumsuz ifadeleri

\begin{tabular}{llc}
\hline Tema & \multicolumn{1}{c}{ Olumsuz öğrenci ifadesi } & $\begin{array}{c}\text { Frekans } \\
\text { (f) }\end{array}$ \\
\hline Grup & "Grup arkadaşları olarak anlaşamayanlar vardı bizim için öyle bir şey & 1 \\
Çalışması & yoktu ama grup olarak böyle bir durum olumsuzluk olarak söylenebilir. & \\
& Onları zaylflatabilir” (DGÖ-5) & 1 \\
Zaman & "Olumsuz yanı zaman allyor, çok yorucu oluyor” (DGÖ-3) \\
\hline
\end{tabular}

Tablo 12'deki öğrenci ifadeleri incelendiği zaman grup arkadaşları arasındaki anlaşmazlığın grup çalışmasını olumsuz etkilediğini ve proje tabanlı öğrenmenin zaman alıcı olmasından dolayı yorucu buldukları görülmektedir.

Tablo 13'te kontrol grubu öğrencilerinin uygulama sürecine yönelik olumlu görüşleri görülmektedir.

Tablo 13. Kontrol grubu öğrencilerinin yarı yapılandırılmış görüşmelerinin içerik analizi ve olumlu ifadeleri

\begin{tabular}{llc}
\hline Tema & \multicolumn{1}{c}{ Olumlu öğrenci ifadesi } & $\begin{array}{c}\text { Frekans } \\
\text { (f) }\end{array}$ \\
\hline & & \\
Öğretmen & "Ben öğretmen merkezli ĕgitimden yanayım. Eski kafalıyım ben. & 1 \\
Merkezli & $\begin{array}{l}\text { Öğrenciden çok ögretmenin bilgisi olduğu için bilgiyi kazanmak } \\
\text { Eğitim }\end{array}$ & \\
\hline
\end{tabular}

Tablo 13'te öğrenci ifadesi incelendiğinde öğrencinin öğretmen merkezli eğitimi önemli bulduğu görülmektedir. 
Tablo 14'de kontrol grubu öğrencilerinin uygulama sürecine yönelik olumsuz görüşleri görülmektedir.

Tablo 14. Kontrol grubu öğrencilerinin yarı yapılandırılmış görüşmelerinin içerik analizi ve olumsuz ifadeleri

\begin{tabular}{|c|c|c|}
\hline Tema & Olumsuz öğrenci ifadesi & $\begin{array}{c}\text { Frekans } \\
\text { (f) }\end{array}$ \\
\hline Yöntem & $\begin{array}{l}\text { "Sadece ögretmen anlattığl için sebep sonuç tamamen hayal } \\
\text { gücüne bağlı ögrenci ne kadar alırsa o kadar oluyor, bazı } \\
\text { şeyler eksik kalabiliyor. Öğretmenin nasıl anlattı̆̆ önemli" } \\
(K G O ̈ ~ 1) .\end{array}$ & 1 \\
\hline $\begin{array}{l}\text { Akılda } \\
\text { Kalıcılık }\end{array}$ & $\begin{array}{l}\text { "O işi yapan yere gezi yapılsa cihazın nasıl çalıştı̆̆ } \\
\text { analizleri ondan görsek daha akılda kalıcı olurdu" (KGÖ 2). }\end{array}$ & 1 \\
\hline $\begin{array}{l}\text { Öğrenci } \\
\text { İlgisi }\end{array}$ & $\begin{array}{l}\text { "Dersi anlatan öğretmen sinıfa hakim olamıorsa } \\
\ddot{o g} r e n c i l e r i n ~ i l g i l e r i f a r k l \text { yöne kayıyor" }(K G O ̈ 1) .\end{array}$ & 2 \\
\hline
\end{tabular}

Kontrol grubu öğrencilerinin öğretmen merkezli eğitimde öğretmenin anlatımın önemli olduğunu ve anlatımın yanında değişik etkinliklerin yapılması gerektiğini ifade ettikleri Tablo 14'de görülmektedir.

Deney ve kontrol grubu öğrencilerinin yarı yapılandırılmış görüşmelerde " $\mathrm{Mn}^{7+}, \mathrm{Cu}^{2+}$ ya da $\mathrm{Cr}^{6+}$ iyonlarını içeren bir çözeltinin nicel analizinde nasıl bir yol izlersin?” sorusuna vermiş oldukları cevaplardan birer örnek Tablo 15'de verilmiştir.

Tablo 15. Deney ve kontrol grubu öğrencilerinin yarı yapılandırılmış görüşmelerde konuya yönelik sorulan soruya vermiş oldukları cevap örnekleri

\begin{tabular}{ll}
\hline Öğrenci & Öğrenci ifadesi \\
\hline DGÖ-1 & "Spektroskopik yöntemle. UV-GB spektrofotometresi ile. UV-GB de 400-700 nm arasında \\
& çalıştık. Mesela bakırı tayin ederken kör çözelti olarak NH. kullandık. Neden? Cu elementi \\
& $\mathrm{NH}_{3}$ ile kompleks yapıyor o yüzden. Kompleks oluşturarak renkleniyor. Rengin şiddetini \\
& değiştirmiş oluyoruz. Kör su ve amonyak olucak. Ilk önce dalga boyu taramast yapıyoruz. \\
& Taramadan sonra pikler oluşuyor. En yüksek abs. Değerinde ki dalga boyunu alıyoruz. \\
& Değişik derişimlerde çözeltiler hazırlayarak A-C (absorbans-konsantrasyon) grafiğini \\
& oluşturduk. Kalibrasyon eğrisi yani doğrusal bir çizgi oluşturuyoruz. Numuneyi cihaza \\
& koyup absorbansını okurum. Grafikten derişime geçerim. Diğerlerinin tayini için kör \\
& çözeltiler farklı oluyor işlem aynı"
\end{tabular}
KGÖ-2 "Geçen dönem analitikte çeşitli maddeler ekleyerek kalitatif analiz yapmıştık. Çeşitli maddeler ekleyip renk değişimi çökelek e bakıyorduk. Cu var mı yok mu anllyorduk. Ne kadar olduğunu nasıl bulursun. Titrasyonla yapabiliriz. UV-GB ile bulabiliriz. Maddenin içine ışık gönderip 400-700 nm arasında GB deki maddelerin ne kadar olduğuna bakabiliriz. Bu kadar hatırlayabiliyorum."

Öğrencilerin bu soruya vermiş oldukları cevaplar incelendiğinde; deney grubu öğrencilerinin daha bilimsel ve ayrıntılı cevap verebildikleri görülmektedir. Elde edilen bulgular; öğrencilerin konuyu anlama düzeylerinde proje tabanlı öğrenme yaklaşımının daha etkili olduğu şeklinde yorumlanabilir.

\section{TARTIŞMA ve SONUÇ}

$\mathrm{Bu}$ çalışmada; proje tabanlı öğrenme yaklaşımının Analitik Kimya Laboratuvar dersi "Işık-madde etkileşimine dayanan UV/Görünür bölge 
spektroskopik analiz yöntemi uygulamaları" konusunda öğrencilerin akademik başarısına etkisi incelenmiştir. Çalışma deney ve kontrol grubu öğrencileri ile yarı deneysel modele göre yürütülmüştür. Deney grubu öğrencileri ile konu proje tabanlı öğrenme yaklaşımı ile, kontrol grubu öğrencilerinde ise öğretim programına uygun laboratuvar uygulamaları ile yürütülmüştür. Ön ve son test olarak uygulanan 7 açık uçlu soruya deney ve kontrol grubu öğrencilerinin vermiş oldukları cevaplar kategorize edilerek içerik analizleri yapılmıştır. Deney ve kontrol grubu öğrencilerinin açık uçlu sorulardan almış oldukları akademik başarı puanları ise Mann-Whitney $U$ ve Wilcoxon işaretli sıralar testi ile analiz edilmiştir. MannWhitney U testi sonuçları; ön test akademik başarı puanları arasında gruplar arasında anlamlı bir farklılığın olmadığını, son test akademik başarı puanları arasında ise deney grubu lehine anlamlı bir farklılık olduğunu göstermiştir. Wilcoxon işaretli sıralar testi sonuçları; hem deney hem de kontrol grubu öğrencilerinin ön ve son test akademik başarı puanları kıyaslandığında, her iki grupta da son test akademik başarı puanlarının arttığını göstermektedir. Ancak, akademik başarı puanlarındaki artışın proje tabanlı öğrenme yaklaşımı uygulanan deney grubu öğrencilerinde daha fazla olması, proje tabanlı öğrenme yaklaşımının akademik başarıyı artırmada daha etkili olduğu şeklinde yorumlanabilir. Ayrıca hesaplanan Cohen's d $(\mathrm{d}=0,88)$ değeri de proje tabanlı öğrenme yaklaşımının öğrencilerin akademik başarısı üzerinde büyük etkiye sahip olduğunu göstermektedir. Ayaz ve Söylemez (2015) yaptıkları meta analiz çalışmasında; proje tabanlı öğrenme yaklaşımının fen derslerinde öğrencilerin akademik başarısı üzerindeki etki büyüklüğünün yüksek düzeyde olduğunu ve öğrenci sayısının 1-50 aralığında seçilmesinin de etki büyüklüğü değerini olumlu yönde etkilediğini belirlemişlerdir.

İlgili alan yazın incelendiğinde; proje tabanlı öğrenme yaklaşımının öğrencilerin akademik başarısını arttırdığına yönelik çalışmaların bulunması çalışma sonucunu destekler niteliktedir. Barak ve Dori (2005) yaptıkları çalışmada proje tabanlı öğrenmenin öğrencilerin başarısı üzerine etkisini incelemişler ve deney grubu öğrencilerinin kontrol grubu öğrencilerine kıyasla daha başarılı olduklarını açığa çıkarmışlardır. Korkmaz ve Kaptan (2002) çalışmalarında, deneysel süreç sonunda akademik başarı açısından deney grubu lehine anlamlı fark bulmuşlardır. Gültekin (2007) yaptığı çalışmada, proje tabanlı örenmenin öğrenci başarısı üzerindeki etkisine bakmıştır. Baran ve Maskan (2010) yaptıkları çalışmada, proje tabanlı öğrenmenin öğrencilerin elektrostatik konusundaki başarılarına etkisini incelemişler ve uyguladıkları kavram başarı testinin analizi sonucunda deney grubu lehine anlamlı bir fark bulmuşlardır. Panasan ve Nuangchalerm (2010) yaptıkları çalışmada, proje tabanlı öğrenme yaklaşımının başarı açısından oldukça etkili ve geçerli olduğunu bulmuşlardır.

Uygulama süreci sonrasında son testte; deney grubu öğrencilerinin açık uçlu sorularda yer alan özellikle laboratuvar uygulamalarına yönelik sorulan sorularda, kontrol grubu öğrencilerine kıyasla daha yüksek oranda tam doğru cevap verebildikleri gözlenmiştir. Bunun nedeni olarak; proje tabanlı öğrenme yaklaşımında uygulanan grup araştırmasına olanak sağlayan laboratuvar deneyimlerinin, proje konusuna yönelik çözüm sürecinin ve yeni öğretim stratejilerinin öğrencilerin başarısında etkisinin olabileceği düşünülmektedir. Proje tabanlı laboratuvar yaklaşımı ve grup çalışmasının öğrenci başarısında etkili olduğunu destekleyen çalışmalar mevcuttur. Amarasiriwardena (2007), proje tabanlı laboratuvar yaklaşımı kullanarak çevre kimyasında analitik atomik spektroskopi öğretimi için yaptığı çalışmasında 
proje tabanlı laboratuvar yaklaşımının sınıf üyeleri arasında ekip çalışmasını güçlü bir şekilde teşvik ettiğini ve öğrencilerin hedef odaklı görevleri yerine getirmek için bir takım olarak çalıştıklarını ortaya koymuştur. Ayrıca projelerin disiplinler arası bilimsel bilgiyi de geliştirdiğini açığa çıkarmıştır. Juhl ve diğerleri (1997), pestisit analizleri için GC/MC analizleri içeren projeler yapmışlar ve çalışmalarının sonucunda proje tabanlı öğrenme yaklaşımının iletişim becerilerini ve kişiler arası ilişkileri arttırdığı sonucuna ulaşmışlardır. Adami (2006) yılında yaptığı çalışmasında projeye bağlı olan laboratuvar aktivitelerinin öğrencilerin önemli teknik enstrüman becerilerini ve kişiler arası iletişimi arttırdığı sonucuna ulaşmıştır.

Deney ve kontrol grubu öğrencilerinin uygulama sürecine yönelik görüşlerini belirlemek üzere yapılan yarı yapılandırılmış görüşme sonuçları; deney grubu öğrencilerinin proje tabanlı öğrenme yaklaşımına yönelik çoğunlukla olumlu görüşe sahip olduklarını, kontrol grubu öğrencilerinin ise daha çok olumsuz görüşe sahip olduklarını göstermiştir. Deney grubu öğrencilerinin; proje tabanlı öğrenmenin kişiler arası iletişim ve paylaşımı arttırdığı, bu şekilde yapılan ders sonucu teorik bilgiyi uygulama şansı buldukları ve bu sayede konunun daha akılda kalıcı olduğu ve öğrencilerin bir görevi yerine getirmek için grup halinde çalışmayı öğrendikleri şeklinde görüşlere sahip oldukları belirlenmiştir. Deney grubu öğrencileri proje tabanlı öğrenme yaklaşımını ilk duyduklarında tedirgin olmuş olsalar bile, projede çalışmaya başladıktan sonra keyif aldıklarını ve bilgilerin daha akılda kalıcı olduğunu ifade etmişlerdir.

Kontrol grubu öğrencileri ise uygulanan süreçte dersi yürüten kişinin etkisinden söz etmiş, dersin akılda kalıcılığı ve ilgi çekiciliğinin dersi yürüten kişiye bağlı olmasını bir olumsuzluk olarak ifade etmişlerdir.

Yarı yapılandırılmış görüşmeler sırasında öğrencilere konuya yönelik sorulan bilimsel sorunun cevapları analizlendiğinde; deney grubu öğrencilerinin soru ile ilgili daha ayrıntılı ve bilimsel cevaplar verebildiği, kontrol grubu öğrencilerinin cevaplarının daha yüzeysel kaldığı görülmüştür. Bu sonuç deney grubu öğrencilerinin konuyu anlama düzeylerinin daha iyi olduğu şeklinde yorumlanabilir.

Çalışmanın sonuçları genel olarak değerlendirildiğinde; proje tabanlı öğrenme yaklaşımının analitik kimya laboratuvar uygulamasının öğrencilerin akademik başarısını ve kişiler arası etkileşimi arttırması açısından tercih edilebileceği görülmektedir. Proje tabanlı öğrenme yaklaşımının dezavantajı ise uzun zaman alması, bu nedenle öğrencilerin süreci yorucu bulmalarıdır. Proje tabanlı öğrenme yaklaşımı ile bu konunun farklı öğrenci grupları ile de çalışılarak yaygın etkisi artırılabilir. Ülkemizde proje tabanlı öğrenme yaklaşımının uygulandığı yüksek lisans ve doktora tezleri incelendiğinde; bu yaklaşımın 56 tezden 49 tanesinde akademik başarıyı artırmada etkili olduğu ancak üniversite düzeyinde yapılan çalışmaların sınırlı sayıda olduğu $(\% 17,1)$ görülmektedir (URL3). Proje tabanlı öğrenme yaklaşımının üniversite düzeyinde kimya öğretmen adaylarının akademik başarısını arttırmış olması ve uygulama sürecine yönelik çoğunlukla olumlu görüşe sahip olmaları nedeniyle; üniversite düzeyinde yapılan çalışmaların yüzdesinin az olması göz önüne alınırsa bu yaklaşımın üniversite düzeyinde uygun olan diğer konularda uygulanması önerilebilir. 


\section{KAYNAKLAR}

Adami, G. (2006). A new project based lab for undergraduate environmental and analytical chemistry. Journal of Chemical Education, 83(2), 253-256.

Amarasiriwardena, D. (2007). Teaching analytical atomic spectroscopy advances in an environmental chemistry class using a project-based laboratory approach: investigation of lead and arsenic distributions in a lead arsenate contaminated apple orchard. Analytical and Bioanalytical Chemistry, 388, 307-314.

Apedoe, X.S., Ellefson, M.R. \& Schunn, C.D. (2012). Learning together while designing: Does group size make a difference?. Journal of Science Education Technology, 21, 83-94.

Arnold, R. J. (2003). The water project: A multi - week laboratory project for undergraduate analytical chemistry. Journal of Chemical Education, 80(1), 5860 .

Atıc1, B., \& Polat, H. (2010). Web tasarımı öğretiminde proje tabanlı öğrenme yaklaşımının öğrencilerin akademik başarısı ve görüşlerine etkisi. Turkish Journal of Computer and Mathematics Education, 1(2), 122-132.

Ayaz, M.F. \& Söylemez, M. (2015). The Effect of the Project Based Learning Approach on the Academic Achievements of the Students in Science Classes in Turkey: A Meta - Analysis Study, Education and Science, 4(178), 255-283.

Balc1, A. (2001). Sosyal bilimlerde araştırma: Yöntem, teknik ve ilkeler. (3. Baskı). Ankara: PegemA Yayınevi.

Baran, M., \& Maskan, A. (2010). The effect of project based learning on pre-service physics teachers' electrostatic achievements. Cypriot Journal of Educational Sciences, 5, 243-247.

Baran, M. (2011). Teknoloji ve proje tabanlı öğrenme yaklaşımı destekli düşünce yolculuğu tekniğinin lise 11. sinı ögrencilerinin fizik başarılarına ve akademik benlik tasarımlarına etkisi, Doktora Tezi, Dicle Üniversitesi Fen Bilimleri Enstitüsü, Diyarbakır.

Barak, M., \& Dori, Y.J. (2005). Enhancing undergraduate student's chemistry understanding through project based learning in an IT environment. Science Education, 89(1), 117-139.

Başkan Takoğlu, Z., \& Alev, N. (2015). Fen bilgisi öğretmen adaylarının matematiksel modelleme yapabilme becerilerinin gelişimi. Dicle Üniversitesi Ziya Gökalp Ĕ̌itim Fakültesi Dergisi, 24, 122-160.

Bell, S. (2010). Project based learning for the 21st Century: Skills for the future. The Clearing House, 83(2), 39-43.

Büyüköztürk, Ş. (2006). Sosyal bilimler için veri analizi el kitabı (6. Baskı). Ankara: PegemA Yayıncilik.

Büyüköztürk, Ş., Çokluk, Ö., \& Köklü, N. (2010). Sosyal bilimler için istatistik (5. Baskl). Ankara: Pegem Akademi Yayıncılık.

Cansüngü-Koray, Ö., \& Bal, Ş. (2002). İlköğretim 5. ve 6. sınıf öğrencilerinin 1şık ve 1şığın hızı ile ilgili yanlış kavramları ve bu kavramları oluşturma şekilleri, G. $\ddot{U}$. Gazi Eğitim Fakültesi Dergisi, 22(1), 1-11.

Christensen, L.B. Johnson, R.B., \& Turner, L.A. (2015). Research Methods Design and Analysis (Çeviri Editörü: Aypay, A. Araştırma Yöntemleri Desen ve Analiz). Ankara: Anı Yayınc1lık.

Cohen, J. (1988). Statistical power analysis for the behavioural sciences (2nd edition). Hillsdale NJ: Erlbaum. 
Coştu, B., Ünal,S., \& Ayas, A. (2007). Günlük yaşamdaki olayların fen bilimleri ögretiminde kullanılması. Ahi Evran Üniversitesi Kırşehir Eğitim Fakültesi Dergisi, 8(1), 197-207.

Diaz-Vázquez, L.M., Casañas, B., Echeyarría, I., Hernández, G., Illán, F.G., Calzada, A.M., et al. (2012). An investigative, cooperative learning approach for general chemistry laboratories. International Journal for the Scholarship of Teaching and Learning, 6(2), 1-14.

Doğanay, A., Demircioğlu, T., \& Yeşilpınar, M. (2014). A need assessment study for an interdisciplinary curriculum about natur of science for prospective elementary teachers. Turkish studies - International Periodical for the Languages, Literature and History of Turkish or Turkic, 9(5), 777-798.

Extrom, C.L., \& Mosher, M.D. (2000). A novel high school chemistry camp as an outreach model for regional colleges and universities. Journal of Chemical Education, 77(10), 1295-1297.

Feyzioğlu, B., Demirdağ, B., Ateş, A., Çobanoğlu, İ., Altun, E., \& Akyıldız, M. (2011). Laboratuvar uygulamalarına yönelik öğrenci görüşleri: İzmir ili örneği. Ilkögretim Online, 10(3), 1208-1226.

Ferguson, G.A. \& Takane, Y. (1989). Statistical analysis in psychology and education (Sixth Edition). New York: McGraw Hill Publication.

Fraenkel, J.R., \& Wallen, N.E. (2005). How to design and evaluate research in education (6th ed.). New York: McGraw-Hill International Edition.

Gülbahar, Y., \& Tinmaz, H. (2006). Implementing project - based learning and eportfolio assessment in an undergraduate course. Journal of Research on Technology in Education, 38(3), 309-327.

Gültekin, M. (2005). The effect of project based learning on learning outcomes in the 5 th grade social studies course in primary education, Educational Sciences: Theory \& Practice, 5(2), 548-556.

Gültekin, M. (2007). Proje tabanlı öğrenmenin beşinci sınıf fen bilgisi dersinde öğrenme ürünlerine etkisi. Ilköğretim Online E-Dergisi, 6(1), 93-112.

Gündüz, T. (2007). Instrümental analiz (10. Baskı). Ankara: Gazi Kitabevi.

Harle, H.D., Leber, P.A., Hess, K.R., \& Yoder, C.H. (2003). A concept based environmental project for the first-year laboratory: Remediation of bariumcontaminated soil by in situ immobilization. Journal of Chemical Education, $80(5), 561-562$.

İmer, N. (2008). Illkögretim fen ve teknoloji öğretiminde proje tabanlı ögrrenme yaklaşımının öğrencilerin akademik başarı ve tutumlarına etkisinin araştırılması. Yüksek lisans tezi. Gazi üniversitesi Eğitim Bilimleri Enstitüsü, Ankara.

Juhl, L. Yearsley, K., \& Silva, A.J. (1997). Interdiciplinary project based learning through an environmental water quality study. Journal of Chemical Education, 74(12), 1431-1433.

Karasar, N. (2003). Bilimsel araştırma yöntemleri (12. Baskl). Ankara: Nobel Yayıncılık.

Korkmaz, H. \& Kaptan, F. (2002). Fen eğitiminde proje tabanlı öğrenme yaklaşımının ilköğretim öğrencilerinin akademik başarı, akademik benlik kavramı ve çalışma sürelerine etkisi. Hacettepe Üniversitesi Eğitim Fakültesi Dergisi, 22, 91-97. 
Morgil, İ. Güngör Seyhan, H., \& Seçken, N. (2009). Proje destekli kimya laboratuvarı uygulamalarının bazı bilişsel ve duyuşsal alan becerilerine etkisi. Türk Fen Eğitimi Dergisi, 6(1), 89-107.

O’Hara, P.B. \& Sanborn, J.A. (1999). Pesticides in drinking water: Project based learning within the introductory chemistry curriculum. Journal of Chemical Education, 76(12), 1673-1677.

Panasan, M., \& Nuangchalern, P. (2010). Learning Outcomes of Project Based and Inquiry-Based Learning Activities, Journal of Social Sciences, 6(2), 252-255.

Şahin, F. \& Kargın, T. (2013). Sınıf öğretmenlerine üstün yetenekli öğrencilerin belirlenmesi konusunda verilen bir eğitimin öğretmenlerin bilgi düzeylerine etkisi. Ankara Üniversitesi Eğitim Fakültesi Özel Ĕ̆itim Dergisi, 14(2), 1-13.

Şaşmaz Ören, F., \& Erdem, Ş. (2014). Fen ve teknoloji dersi '1şık' ünitesine yönelik rehber materyal geliştirme çalışması, Ĕgitim ve Öğretim Araştırmaları Dergisi, $3(3), 223-233$.

Selco, J.J., Roberts, J.L., \& Wacks, D.B. (2003). The analysis of seawater: A laboratory-centered learning project in general chemistry. Journal of Chemical Education, 8(1), 54-57.

Sert Çıbık, A., \& Yalçın, N. (2012). Analojilerle desteklenmiş proje tabanlı öğrenme yönteminin fen bilgisi öğrencilerinin fizik dersine yönelik tutumlarına etkisi. Gazi Üniversitesi Ĕ̈itim Fakültesi Dergisi, 32(1), 185-203.

Sert Çıbık, A., \& İnce Aka, E. (2016). Genel fizik laboratuvarı 11 dersinde kullanılan proje tabanlı öğretim yönteminin öz-yeterlilik, tutum ve başarıya etkisi. Kastamonu Ĕ̆itim Dergisi, 24(2), 511-534.

Şen, A. İ. (2003). İlköğretim öğrencilerinin 1 şık, görme ve aynalar konusundaki kavram yanılgılarının ve öğrenme zorluklarının incelenmesi. Hacettepe Üniversitesi Ĕ̆itim Fakültesi Dergisi, 25, 176-185.

Taşlıdere, E., \& Bedur, S. (2015). Düz anlatım yöntemi kullanılan öğretimin fen bilgisi öğretmen adaylarının 1şığın mercek ile etkileşimi konusundaki anlamalarına etkisi. Mehmet Akif Ersoy Üniversitesi Eğitim Fakültesi Dergisi, 33, 105-129.

Türkmen, L. \& Yalçı, M. (2001). Bilimin doğası ve eğitimdeki yeri. Afyon Kocatepe Üniversitesi Sosyal Bilimler Dergisi, 3(1), 189-195.

Türnüklü, A. (2000). Eğitimbilim araştırmalarında etkin olarak kullanılabilecek nitel bir araştırma tekniği: görüşme. Kuram ve Uygulamada Ĕgitim Yönetimi, 24, 543-559.

Uzoğlu, M., Yıldız, A., Demir, Y., \& Büyükkasap, E. (2013). Fen bilgisi öğretmen adaylarının 1şıkla ilgili kavram yanılgılarının belirlenmesinde kavram karikatürlerinin ve açık uçlu soruların etkililiklerinin karşılaştırılması. Ahi Evran Üniversitesi Kırşehir Eğitim Fakültesi Dergisi (KEFAD), 14(1), 367388.

Ünal Çoban, G., \& Ergin, Ö. (2013). Modellemeye dayalı fen öğretiminin etkilerinin bilimsel bilgi açısından incelenmesi. Hacettepe Eğitim Fakültesi Dergisi, 28(2), 505-520.

Yeşilyurt, M. Bayraktar, Ş., Kan, S., \& Orak, S. (2005). İlköğretim öğrencilerinin 1şık kavramı ile ilgili düşünceleri. Yüzüncü Yll Üniversitesi Eğitim Fakültesi Dergisi (htpp://efdergi.yyu.edu.tr), 2(1), 1-24.

Yıldırım, A. \& Şimşek, H. (2006). Sosyal bilimlerde nitel araştırma yöntemleri (Altıncı Baskl). Ankara: Seçkin Yayınevi. 
Yıldız, A. Genç, Ö., \& Bektaş, Ş. (1997). Enstrümental analiz yöntemleri (İkinci Baskl). Ankara: Hacettepe Üniversitesi Basımevi.

Yiğit, N. (2007). Bilimsel araştırmalarda veri analizi ve yorum. D.Ekiz.(Ed.), Bilimsel Araştırma Yöntemler. İstanbul: Lisans Yayıncılık.

URL 1: Bilimsel yöntemin çözüm aşamaları. http://www.bilgicik.com/yazi/bilimselyontemin-çozum-asamalari/ (Erişim tarihi: 25.01.2017).

URL 2: Gökkuşağ1 oluşumu. Htpp://www.forumdas.net/forum/konu/gokkusagi-nasilolusur-ozet.187056/ (Erişim tarihi: 25.01.2017).

URL 3: Çelik, C.H. ve Gündüz, S. Proje Tabanlı Öğrenme Yaklaşımını Temel Alan Çalışmaların Değerlendirilmesi: Türkiye Örneği. (8. Ulusal Eğitim Yönetimi Kongresi) http://coskunc.siirt.edu.tr/files/ProjeTabanlrenmeBildiri.pdf (Erişim tarihi: 25.01.2017). 


\section{Introduction}

\section{EXTENDED ABSTRACT}

Chemistry in the field of science includes discrete and complex subjects. Students have difficulty learning chemistry topics that contain complex and abstract concepts. In order to avoid the difficulties of understanding chemistry topics, it is important that the concepts are explained in concrete form. This is possible by using appropriate teaching methods in lessons (Díaz-Vázquez et al., 2012; Apedeo, Ellefson \& Schunn, 2012; Sert Çıbık \& Yalçın, 2012). To increase students' access, suitable active learning methods improving students' problem solving skills and remove them from memorization should be used. One of them is the project based learning approach.

In recent years, science educators have been trying to practices appropriate to the scientific process in order to facilitate the learning of students and enable them to learn effectively (Díaz-Vázquez et al., 2012; Feyzioğlu et al., 2011). Some researchers combined project based learning approach with experiments in the laboratory (O'Hara \& Sanborn, 1999; Exstrom \& Mosher, 2000; Juhl et al., 1997; Harle et al., 2003; Selco et al., 2003; Arnold, 2003). In this way students' creating product ability was developed by researching and examine their findings (Morgil, Seyhan \& Seçken, 2009).

In the chemistry education, laboratory courses that students take during their undergraduate program allow students to gain basic laboratory skills. It is very significant for the students to be able to bring up a solution for problems by making independent elections as well as the basic laboratory skills because of providing an effective teaching environment (Adami, 2006). Students can become familiar with the scientific method and be able to suggest solutions to problems with the application of the Project based learning approach.

\section{Purpose}

In this work, to live the scientific research process with group study, to product a project product, to introduce UV/Visible spectrophotometer, to gain knowledge about its theory and to be able to applications related to the spectroscopic analysis method of the students in studying "Application of UV/Visible spectroscopic analysis method based on light-matter interaction" topic with project based learning approach was aimed.

\section{Research Question}

What is the impact of the Project based learning approach on students' academic achievement in the topic of "Application of UV/Visible spectroscopic analysis method based on light-matter interaction?

\section{Method}

Pre- and post-test quasi experimental design with control group was used in this study (Balc1, 2001; Karasar, 2003). The study group of this research consisted of 2nd year students $(\mathrm{N}=24)$ who were educated in Dokuz Eylul University in Chemistry Teacher Education program. Students who took the Analytical Chemistry Laboratory Course for the first time were assigned to the control $(\mathrm{N}=12)$ and experimental $(\mathrm{N}=12)$ groups randomly.

In the experimental group "Application of UV/Visible spectroscopic analysis method based on light-matter interaction" subject was carried out with the project based learning approach and in the control group in accordance with the teaching program during 6 weeks. The application was conducted by the same researchers in both the experimental and control groups. To investigate the impact of the project based learning approach on students' academic achievement, 7 open ended questions were used as both pre- and post-test. Students' opinions about application process was determined by using semi-structured interviews.

\section{Findings}

It can be stated that the project based learning approach is more effective in increasing academic achievement in the teaching of "Application of UV/Visible spectroscopic analysis method 
based on light-matter interaction" subject according to Mann-Whitney U Test analysis results. When Wilcoxon signed rank results are examined to determine students' academic achievement difference before and after the application process, it is observed that there is a significant difference between the pre-test and post-test scores of the students of the experimental group $(\mathrm{z}=3.065, \mathrm{p}<.05, \mathrm{~d}=0.88)$. The obtained data also shows that there is a meaningful difference between the pre-test and post-test scores of the control group students in the laboratory course which is carried out in accordance with teaching program $(\mathrm{z}=2.556, \mathrm{p}<.05, \mathrm{~d}=0.74)$. However, since the median value of the experimental group is higher than that of the control group, it can be interpreted that the applied Project based learning approach is more effective in increasing the academic achievement of the students. It can be also said that the impact size of the project based learning approach is higher than the control group when the effect size $d$ value is considered.

As a result of semi-structured interviews, the students in the experimental group seem to be able to answer more scientifically and in detail. Findings obtained can be interpreted that the project based learning approach is more effective in the students' understanding level.

\section{Discussion and Conclusion}

Mann-Whitney U Test results showed that there was no significant difference between the groups in pre-test academic achievement scores, and there was a significant difference in the post-test academic achievement scores in favour of the experimental group. Wilcoxon signed ranks test results represented that the post-test academic achievement scores of both the experimental and control group students were compared, indicating that post-test academic achievement scores increased in both groups. However, the increase in the academic achievement scores is higher in the experimental group with project based learning approach can be interpreted as that the project based learning is more effective in increasing academic achievement. In addition, the calculated Cohen's $d$ value $(\mathrm{d}=0.88)$ also shows that the project based learning approach has a great influence on the academic achievement of the students.

Considering semi-structured interview results; it was concluded that the experimental group students have more positive opinions than the control group students. It is clear that project-based learning processed with experiment group students have the opportunity to increase interpersonal communication and sharing, to have the opportunity to apply theoretical knowledge as a result of this lesson, and that this is more memorable, and that students have learned to work in groups to perform a task. The control group students mentioned the effect of the lecturer in the process applied and they expressed the negativeness of the fact that the reminder and interest of the lesson depends on the students who are taking the lesson. 
Ek 1. Deney grubu öğrencilerinin proje tabanlı öğrenme yaklaşımı uygulamasından sonra hazırladıkları poster örnekleri
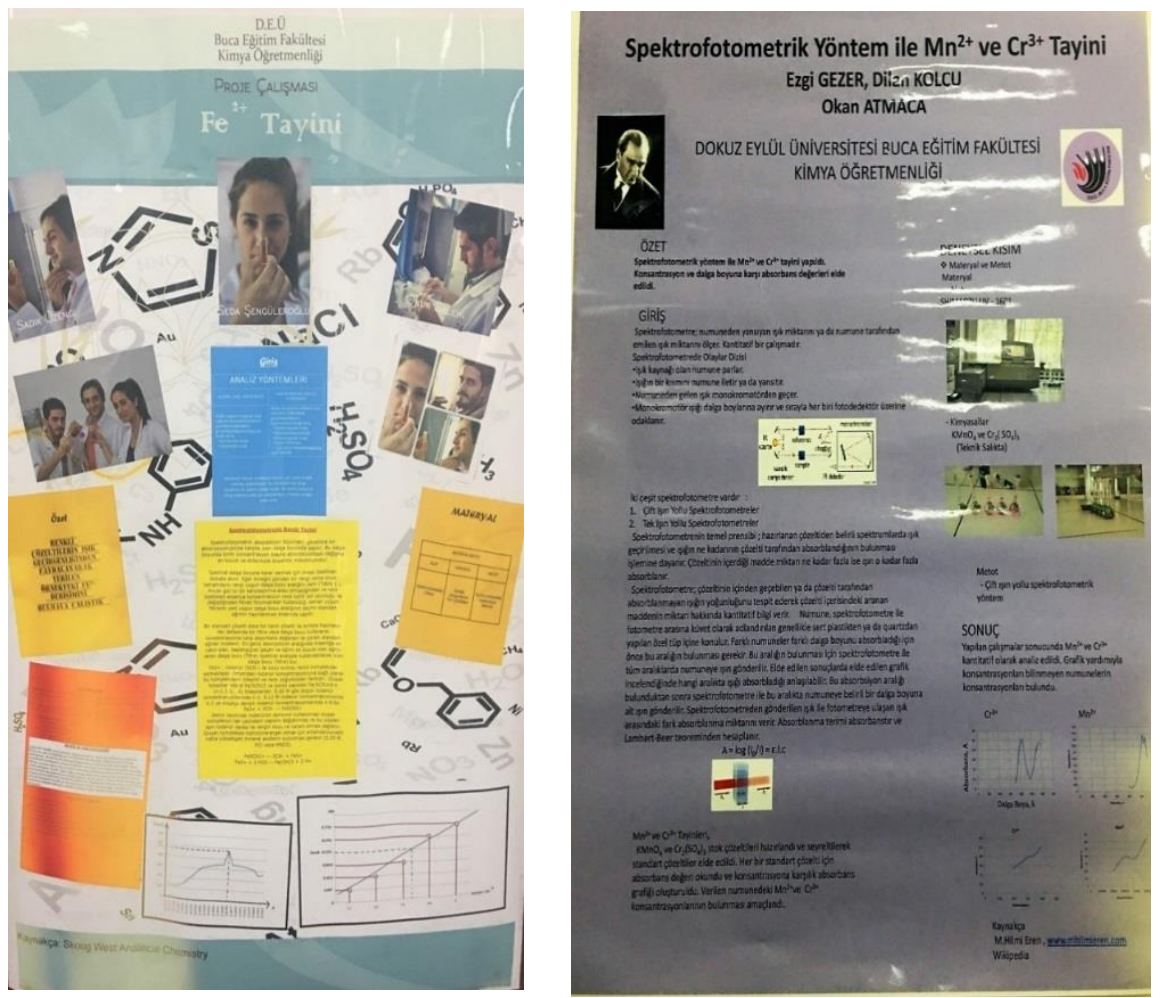